\title{
SEQUENCE SPECIFIC ASSIGNMENT OF THE PROTON NUCLEAR MAGNETIC RESONANCE SPECTRUM OF BARLEY SERINE PROTEINASE INHIBITOR 2
}

\author{
by \\ MOGENS KJÆR "), SVEND LUDVIGSEN"), OLE W. SØRENSEN"), \\ LYDIA A. DENYS ${ }^{(x)}$, JENS KINDTLER ${ }^{(1 \times x)}$ and FLEMMING M. POULSEN ${ }^{(a)}$ \\ 1) Department of Chemistry, Carlsberg Laboratory, \\ Gamle Carlsberg Vej 10, DK-2500 Copenhagen Valby, Denmark \\ 2)Laboratorium für Physikalische Chemie, Eidgenössische Technische \\ Hochschule, $\mathrm{CH}-8092$ Zürich, Switzerland \\ x) Present address: Scripps Clinic \& Research Foundation, Dept. of Molecular Biology MB2, \\ 10666 North Torrey Pines Road, La Jolla, California 92037, USA \\ xx) Present address: A/S Ferrosan, Research Division, \\ Sydmarken 5, DK-2860 Søborg, Denmark \\ a) To whom correspondence should be addressed
}

\begin{abstract}
Keywords: sequential assignment, NMR, COSY, NOESY, Double quantum spectroscopy, serine proteinase inhibitor, protein
\end{abstract}

The sequence specific assignment of the ' $H$ NMR spectrum of barley serine proteinase inhibitor 2 is described. The sequential assignment procedure has been applied to the residues 22 to 83 . The 21 residues in the $\mathrm{N}$-terminal part of the structure were shown to be a random coil for which sequential assignment was not immediately possible. For the C-terminal part of the protein starting at Thr-22 and ending with the $\mathrm{C}$-terminal residue Gly-83, sequence specific assignment of all the $\mathrm{H}^{\mathrm{N}}, \mathrm{H}^{\alpha}, \mathrm{H}^{\mathrm{\beta}}, \mathrm{H}^{\mathrm{\beta}}$ resonances was achieved and complete sequence specific assignment of the non labile protons of the amino acid residue types of glycine, alanine, threonine, serine, valine, isoleucine, leucine, asparagine, aspartic acid, glutamine, glutamic acid, phenylalanine, tyrosine and tryptophan is reported.

\section{INTRODUCTION}

The present paper is the first in a series of papers describing the study by nuclear magnetic resonance spectroscopy of the protein barley serine proteinase inhibitor $2(13,14,22,23)$. The protein was first isolated by MIKOLA and SOULIMNA (1971) (31) and described as an inhibitor of microbial serine proteinases such as

Abbreviations: BSPI-2 - Barley serine proteinase inhibitor 2;(19-83)BSPI-2 = the C-terminal part of BSPI-2 starting at residue 19 and ending at residue 83; CI-I = Barley chymotrypsin inhibitor I; COSY = Two-dimensional correlation spectroscopy; FID = Free induction decay; FT = Fourier transformation. NMR = Nuclear magnetic resonance; NOE = Nuclear Overhauser effect; NOESY = Two-dimensional nuclear Overhauser spectroscopy; ppm = parts per million; $2 \mathrm{QS}$ = Double quantum spectroscopy;. The nomenclature for the atoms of the amino acid was according to the IUPAC-IUB recommendation. (IUPAC-IUB Commission of Biochemical Nomenclature 1969. Biochem. 9 ,3471-3479 (1970)). 
subtilisin. However, it has often been referred to as the chymostrypsin inhibitor, CI-2 (42). The inhibitor is present in relatively large amounts in the seeds of the barley variety HIPROLY (21) where it is responsible for the high content of the amino acids proline and lysine found in the seeds of this variety. The protein consists of 83 residues and it is a basic protein $(20,40)$. The amino acid sequence has been determined using chemical amino acid sequencing (40) and recently from the DNA-sequence of the gene of the inhibitor (53). The amino acid sequence is homologous to the potato serine proteinase inhibitor (41) and has been assigned to the family of inhibitors named after this, which include a number of other inhibitors of plant sources as well as the leech eglin $c(42,44)$. In this family of inhibitors as well as in the entire group of protein inhibitors the BSPI-2 and eglin $c$ are unique sofar in being the only inhibitors which do not contain a disulfide bridge. The three-dimensional structure of the BSPI-2 has been determined by X-ray crystallography firstly in the complex with subtilisin (29) and later in its free form (30). Except for a number of differences in the binding site loop the two structures were in many respects identical. In the binding site loop the peptide bond between Met-59 and Glu- 60 was shown to be hydrolyzed by subtilisin (43). A mechanism of inhibition was deduced from this observation, where the inhibitor is bound to the enzyme and subsequently the active site peptide bond is hydrolyzed. However, due to a very tight binding the inhibitor remains in the active site of the enzyme where it prevents access of other substrates. For a number of reasons the physical and chemical properties of BSPI-2 make this protein inhibitor an ideal protein to study by NMR spectroscopy and other methods: the protein is relatively small, it is very soluble, it remains folded in a $\mathrm{pH}$-range of $\mathrm{pH} 2.8$ to above $\mathrm{pH} 10.5$ at $37^{\circ} \mathrm{C}$ and it undergoes reversible folding-unfolding at conditions close to the point of denaturation. Therefore, the BSPI-2 can serve as a good model protein for studies of chemical properties such as protein dynamics, protein stability, protein electrostatics, protein folding and protein-protein interactions. In addition, since the gene of the BSPI-2 recently has been expressed in E. coli
(FERSHT and LEATHERBOROUGH, personal communication) the protein is subject to chemical modifications employing the techniques of site directed mutagenesis.

The present paper is concerned with the sequential assignment of the ${ }^{1} H$ NMR spectrum of BSPI-2 which is a prerequisite for all further studies of this protein by NMR spectroscopy. The proteins studied here are both the 65 residue long C-terminal part of the protein (19-83)BSPI2 which has been shown to be the core of the protein possessing all the structural features necessary for its function as a proteinase inhibitor (40), and the intact 83 residue long BSPI-2. The sequence specific assignment was achieved by the use of two-dimensional NMR spectroscopy using the information from NOESY, COSY, relayed COSY, 2 QS spectra of both the BSPI-2 and the (19-83)BSPI-2. The principles and the structural basis for the method of sequential assignment of the proton two-dimensional NMR spectrum of proteins were first described by WÜTHRICH et al. (55) and BILLETER et al. (6). The method has since been applied to a number of small proteins such as basic pancreas trypsin inhibitor (47) glucagon (51), bull seminal proteinase inhibitor IIA (39), lac repressor headpiece (57), rabbit methallothionein-2 (8, 33), tendamistat (26), al-purothionin (12), human epidermal growth factor (11), ribosomal protein $\mathrm{E}-\mathrm{L} 30(45,46)$, histidine containing protein from E. coli $(24,25)$, the short scorpion insectotoxin $I_{5} A(3)$, apamin (50), E coli enterotoxin (34), leech eglin (18) phoratoxin (15), hirudin (38), and histone H5 protein (56) for which essentially complete sequence specific assignments have been achieved using the sequential assignment method.

\section{MATERIALS AND METHODS}

The barley serine proteinase inhibitor was extracted from seeds of the barley variety HIPROLY obtained from the Department of Plant Breeding of the Carlsberg Research Laboratory. The extraction and the purification of the BSPI-2 and (19-83)BSPI-2 were in principle as described by JONASSEN (20). All chemicals were analytical grade. Deuterium oxide was purchased from Merck. 
NMR spectra were recorded on a BRUKER AM 500 NMR-spectrometer equipped with an Aspect 3000 computer. The recorded NMR data were transferred to a VAX 11/750 computer and all further data processing was performed using the Carlsberg Laboratory NMR-software which for certain routines uses the Rowland NMRToolkit (17). The following two-dimensional NMR experiments have been used in this work: NOESY $(1,2,19,27,37), \operatorname{COSY}(4,28,33)$, $2 \mathrm{QF}-\operatorname{COSY}(35,36)$ relayed $\operatorname{COSY}(16,49)$ and $2 \mathrm{QS}(7,9,48)$. In all cases the spectra were recorded and transformed using hypercomplex 2D FT yielding quadrature detection in both dimensions and pure phase $(5,32,37)$. The two data sets were recorded with a $90^{\circ}$ relative phase shift of the preparation pulse in the experiments: NOESY, COSY, DQF-COSY and relayed COSY. For the $2 \mathrm{QS}$ experiment a $45^{\circ}$ relative phase shift of the entire preparation pulse "sandwich" was employed. Typically $2 \times 512$ spectra were recorded in the $t_{t}$ domain each of 2048 complex points. When processed the NMR data sets were zerofilled up to 2048 complex points in the $t_{1}$ dimension and 8192 complex points in the $t_{2}$ dimension before the respective Fourier transformations. Chemical shift values are given in $\mathrm{ppm}$ relative to the methyl group proton resonances of 4,4dimethyl-4-silapentane and measured relative to acetone and dioxan as internal standards. The recording of FID's of protein samples in $90 \%$ $\mathrm{H}_{2} \mathrm{O} / 10 \%{ }^{2} \mathrm{H}_{2} \mathrm{O}$ (52) was obtained by continuous selective irradiation at the water resonance frequency in the preparation period and a $3 \mathrm{~dB}$ attenuation of the irradiation during the evolution and the mixing time. The irradiation was gated during the detection period.

\section{RESULTS}

\subsection{Amino acid spin system identification}

The protocol used in the present assignment procedure was as follows. Firstly, the spin systems of the (19-83) BSPI-2 were identified and subsequently, the spin systems of the first eighteen $\mathrm{N}$-terminal residues were identified by comparing the (19-83)BSPI-2 spectrum with the spectrum of the intact BSPI-2 and recognizing those spin systems in the BSPI-2 spectra absent in the (19-83)BSPI-2 spectra.

The spin system recognition was performed as follows. First, the $\mathrm{H}^{\mathrm{N}}-\mathrm{H}^{\alpha}$ cross peaks were registered as found in the socalled "fingerprint region", of the COSY spectrum of (19-83)BSPI-2, Figure 1. This region should contain 60 cross peaks given that the protein contains 65 residues and 4 of these are prolines. In the spectrum 55 cross peaks are labelled according to the result of the sequential assignment. The peaks of Lys-30 and Arg- 67 have been eliminated by the selective irradiation at the water resonance frequen$\mathrm{cy}$, in this spectrum. They have, however, been observed at other conditions. Two $\mathrm{H}^{\mathrm{N}}-\mathrm{H}^{\mathrm{a}}$ cross peaks have never been observed, these are of Leu-20 and Lys- 21 in the N-terminal part of the peptide chain. One cross peak, of Val-79 has so low intensity that it is not appearing in the spectrum at the contouring level used.

Subsequently, the search was initiated for the $\mathrm{H}^{\alpha}-\mathrm{H}^{\beta}$ cross peaks corresponding to each of the $\mathrm{H}^{a}$ chemical shifts identified in the $\mathrm{H}^{\mathrm{N}}-\mathrm{H}^{\alpha}$ cross peak region of the COSY spectrum. The 19 of the 20 amino acids normally found in proteins have a $\beta$-carbon and these can be divided into two groups: one group which contains only one $\beta$-proton include threonine, valine, isoleucine and alanine (which has three $\beta$-protons whose signals, however, degenerates to one) and one group in which the amino acids have two $\beta$-protons consisting of the remaining 15 types of the amino acids normally found in proteins. This latter group can be subdivided into two groups, one which contains the AMX systems: serine, asparagine, aspartic acid, histidine, phenylalanine, tyrosine, tryptophan and cysteine (of which the latter is absent in BSPI-2); and the remaining amino acids which are glutamic acid, glutamine, proline, leucine, methionine, lysine and arginine. Often in COSY spectra of proteins the last group of amino acids, despite of having two $\beta$-protons, only shows one strong $\mathrm{H}^{\alpha}-\mathrm{H}^{\beta}$ COSY cross peak, the cross peak of the second $\mathrm{H}^{a}-\mathrm{H}^{\beta}$ coupling having too low intensity to be observed given the signal to noise ratio typically obtained for protein NMR spectra. In order to obtain definitive identification of the amino acid spin systems belonging to the group having two $\beta$-protons the $\mathrm{H}^{\beta}-\mathrm{H}^{\beta} 2 \mathrm{Q}$ coherence observed 


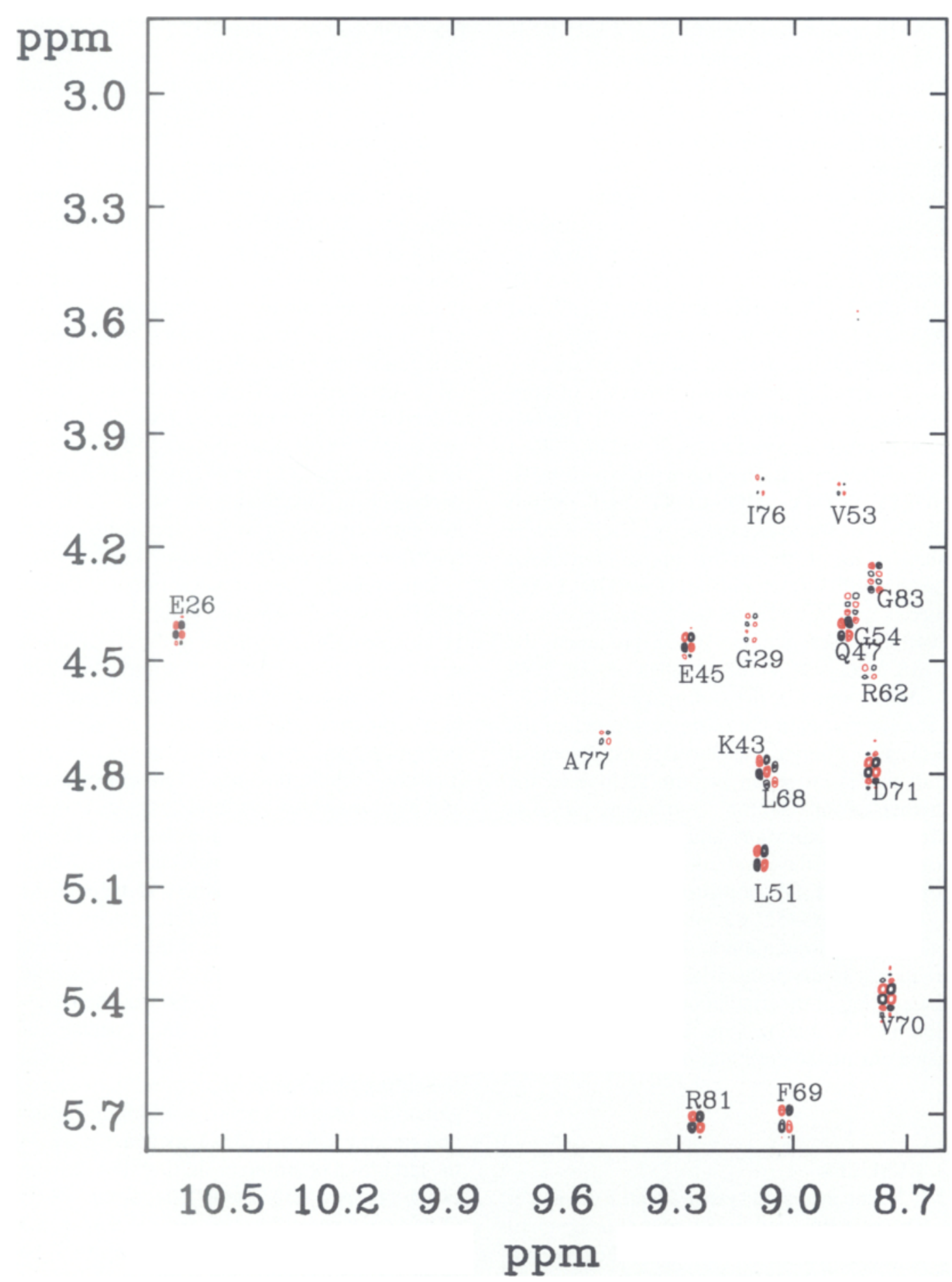

Figure 1. ${ }^{1} \mathrm{H}-{ }^{1} \mathrm{H}$ COSY spectrum of (19-83)BSPI-2 recorded at $42{ }^{\circ} \mathrm{C} \mathrm{pH} 4.20$ in $90 \% / 10 \% \mathrm{H}_{2} \mathrm{O} /{ }^{2} \mathrm{H}_{2} \mathrm{O}$. The region shown is the socalled "fingerprint" region where the $\mathrm{H}^{\mathrm{N}}-\mathrm{H}^{\mathrm{a}}$ cross peaks have been identified. Each cross peak has been labelled with the residue name using the single letter code for the amino acid residues and the residue number according to the sequence determined by SVENDSEN et al, 1980 (40). Red contours are negative levels and black contours are positive levels. 
M. KJÆR et al.: Assignment of the BSPI-2 'H NMR spectrum

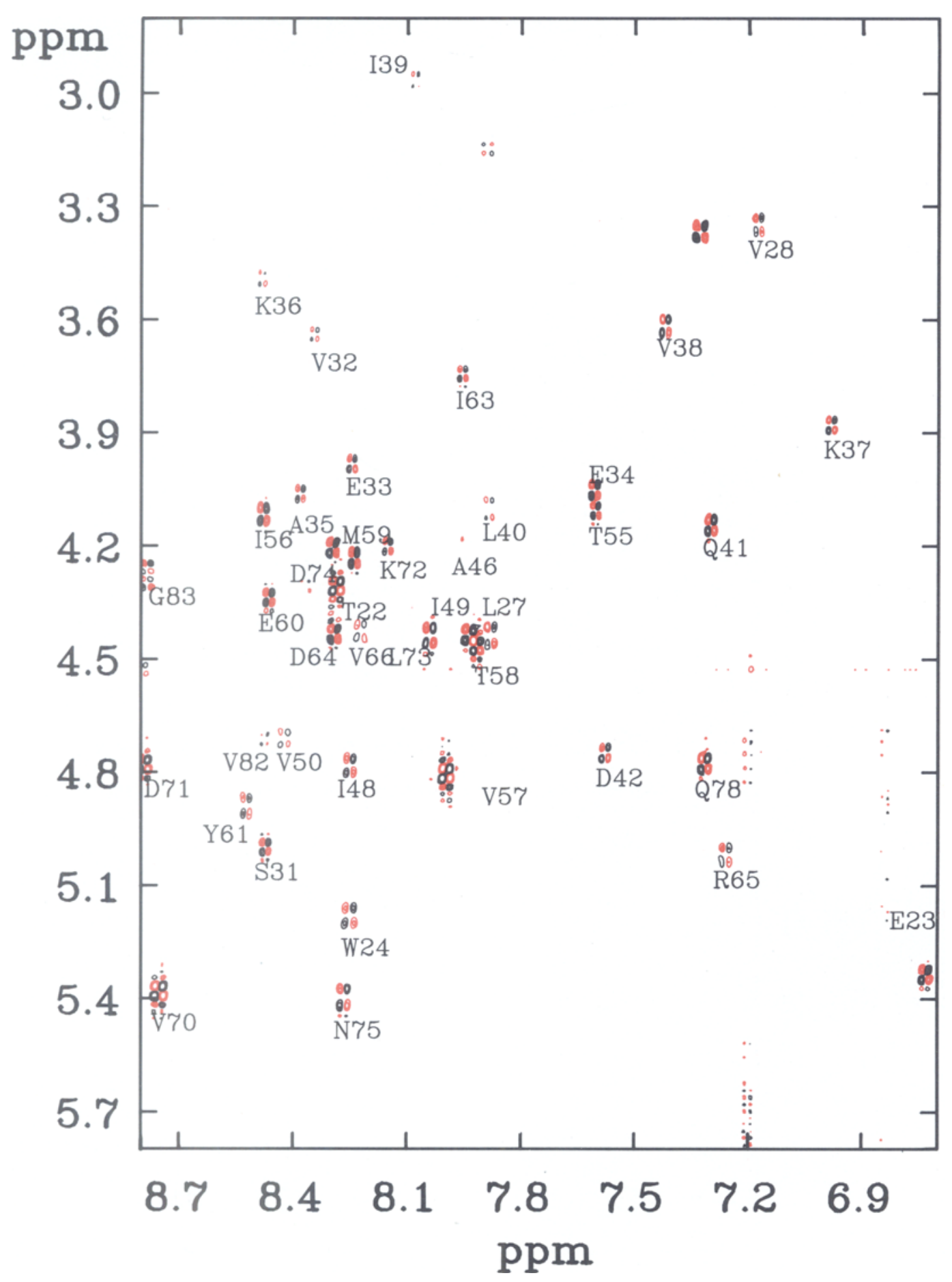




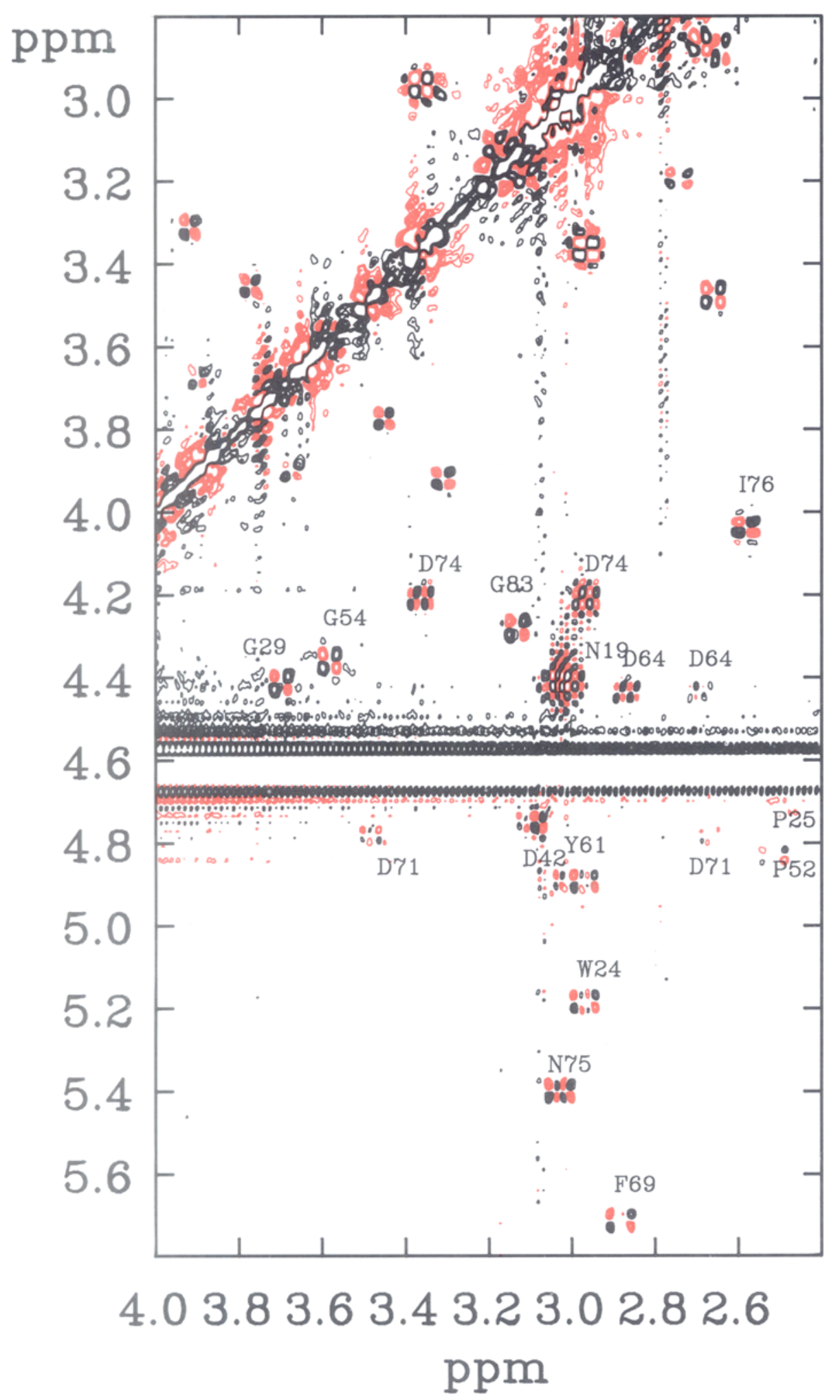




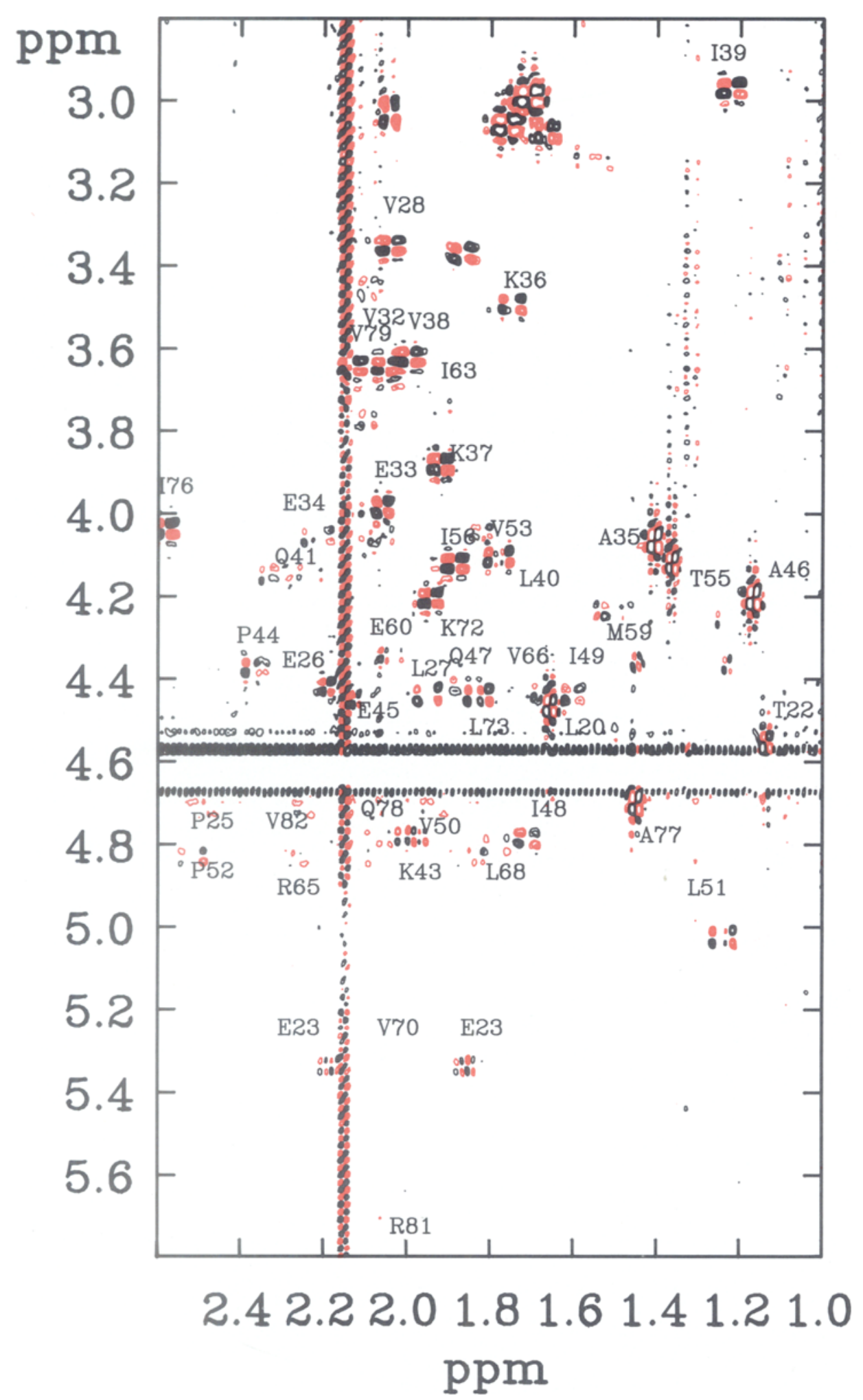


Figure 2. ' $\mathrm{H}-{ }^{-} \mathrm{H}$ COSY spectrum of $0.01 \mathrm{M}$ (19-83)BSPI-2 recorded at $42{ }^{\circ} \mathrm{C}, \mathrm{pH} 4.20$ in $90 \% / 10 \% \mathrm{H}_{2} \mathrm{O} /{ }^{2} \mathrm{H}_{2} \mathrm{O}$. The spectrum shows the $\mathrm{H}^{a}-\mathrm{H}^{\beta}$ cross peaks for most of the residues in the molecule. The cross peaks have been labelled as described in Figure 1.

in double quantum spectra of these amino acids at the $\omega_{2}$ frequency corresponding to the $\mathrm{H}^{\mathrm{a}}$ was employed. So by combination of the COSY and the double quantum spectrum the division of the amino acid spin systems in the two groups was achieved. Subsequently, the cross peaks of the spin systems of the amino acids glycine, alanine, threonine, valine, isoleucine, asparagine, aspartic acid, serine, phenylalanine, tyrosine, tryptophan, were identified using the information available in COSY, relayed COSY, and double quantum spectra. The identification of cross peaks belonging to the spin systems of the remaining amino acids lysine, arginine, methionine, proline, leucine, glutamine and glutamic acid is less easily achieved due to the chemical shift degeneracy of the methylene proton resonances in these amino acids. The identification of these spin systems was therefore postponed to the state in the analysis, where by sequential assignment the $\mathrm{H}^{\mathrm{N}}-\mathrm{H}^{\alpha}$ cross peaks of these amino acids had been identified. The next step in the analysis was the sequential assignment procedure where the neighbouring amino acid spin systems were identified using NOESY spectra. The NOE cross peaks of the type $\mathrm{d}_{\alpha \mathrm{N}}(\mathrm{i}, \mathrm{i}+1)$ and $\mathrm{d}_{\mathrm{NN}}(\mathrm{i}, \mathrm{i}+1)$ were assigned, and by using the information obtained from the identification of the amino acid spin systems in combination with the amino acid sequence, the sequence specific assignment of the individual amino acid spin systems was obtained $(54,57)$. Finally, the identification of the amino acid spin systems remaining to be completed was performed, where this was possible. The following paragraphs will describe in some detail how the procedure described above was used to obtain the sequence specific assignment of the ${ }^{1} \mathrm{H}$ NMR spectrum of BSPI-2.

\subsubsection{Glycines}

The (19-83)BSPI-2 contains three glycines (Gly-29, Gly-54 and Gly-83) and the $\mathrm{H}^{\mathrm{a} 1}-\mathrm{H}^{\mathrm{a} 2}$ cross peaks from these were immediately identified, Figure 2. For two of these glycines the $\mathrm{H}^{\mathrm{N}}-\mathrm{H}^{\mathrm{a}^{\prime}}$ and $\mathrm{H}^{\mathrm{N}}-\mathrm{H}^{\mathrm{a}^{\prime \prime}}$ cross peaks were both sufficiently intense to be observed, but, for the third of the glycines, Gly-83, only one of the $\mathrm{H}^{\mathrm{N}}-\mathrm{H}^{a}$ cross peaks could be identified in the COSY spectrum suggesting that one of the $\mathrm{H}^{\mathrm{N}}-\mathrm{H}^{\mathrm{a}}$ couplings in this residue is very small. This peak, though, was clearly observed in the relayed COSY experiment. Table I lists the chemical shifts of the protons in the three glycines. The additional three glycines in the $\mathrm{N}$-terminal part of the BSPI-2 are clearly observed in the COSY spectrum of the BSPI-2 as three peaks, however, the overlap is so strong that an attempt to distinguish between the three has been avoided.

\subsubsection{Alanines}

The three $\mathrm{H}^{\mathrm{a}}-\mathrm{H}^{\beta(1,2,3)}$ cross peaks of the three alanines Ala-35, Ala-46 and Ala-77 in (19-83)BSPI-2 are shown in Figure 2. They were distinguished from the three threonine $\mathrm{H}^{\beta}-\mathrm{H}^{\gamma(1.2 .3)}$ cross peaks because by coincidence none of the three threonine $\mathrm{H}^{\beta}$ resonances had chemical shifts identical to the identified $\mathrm{H}^{\alpha}$ chemical shifts in the spectrum. In the relayed COSY experiments two of the alanine $\mathrm{H}^{\mathrm{N}}-\mathrm{H}^{\beta(1,2,3)}$ cross peaks were identified and further evidence for the correctness of these assignments were the NOE cross peaks due to strong $\mathrm{H}^{\mathrm{N}}-\mathrm{H}^{\beta(1,2,3)}$ dipolar coupling. The alanine assignments are summarized in Table I. The Ala-14 spin system was unambiguously identified see Figure 3 because Ala- 14 is the only new alanine in the additional $\mathrm{N}$-terminal part of BSPI-2 spectrum.

\subsubsection{Threonines}

Only one of the three $\mathrm{H}^{\alpha}-\mathrm{H}^{\beta}$ cross peaks of the threonines Thr-22, Thr-55, Thr-58 was observed in the COSY spectrum. The remaining two were identified in the double quantum spectrum, which due to the absence of a diagonal facilitates the identification of $\mathrm{J}$-couplings 
Table I. Sequence specific resonance assignment of the proton resonances in BSPI-2 ${ }^{\text {a) }}$.

\begin{tabular}{|c|c|c|c|c|c|c|c|}
\hline \multirow{3}{*}{$\begin{array}{l}\text { Gly } 9 \\
\text { Gly } 13\end{array}$} & \multirow{2}{*}{$\begin{array}{l}\mathrm{H}^{\mathrm{N}} \\
8.35\end{array}$} & \multicolumn{2}{|c|}{$\mathrm{H}^{\alpha^{\prime}}, \mathrm{H}^{\alpha^{\prime \prime}}$} & & & & \\
\hline & & 3.97 & 3.99 & & & & \\
\hline & 8.35 & 3.97 & 3.99 & & & & \\
\hline Gly 15 & 8.35 & 3.97 & 3.99 & & & & \\
\hline Gly 29 & 9.11 & 4.42 & 3.70 & & & & \\
\hline Gly 54 & 8.85 & 4.36 & 3.58 & & & & \\
\hline \multirow[t]{2}{*}{ Gly 83} & 8.79 & 4.28 & 3.12 & & & & \\
\hline & $\mathbf{H}^{\mathrm{N}}$ & $\mathrm{H}^{\alpha}$ & $\mathbf{H}^{\beta}$ & $\mathrm{H}^{\gamma}$ & & & \\
\hline Thr 12 & 8.13 & 4.33 & 4.31 & 1.21 & & & \\
\hline Thr 22 & 8.29 & 4.31 & 4.54 & 1.12 & & & \\
\hline Thr 55 & 7.60 & 4.11 & 4.13 & 1.37 & & & \\
\hline \multirow[t]{2}{*}{ Thr 58} & 7.92 & 4.47 & 4.59 & 1.31 & & & \\
\hline & $\mathrm{H}^{\mathrm{N}}$ & $\mathrm{H}^{a}$ & $H^{\beta}$ & \multicolumn{2}{|c|}{$H^{\gamma}, H^{\gamma}}$, & & \\
\hline Val 3 & b) & 4.16 & 2.11 & 0.94 & 0.94 & & \\
\hline Val 10 & b) & 4.16 & 2.11 & 0.94 & 0.94 & & \\
\hline Val 28 & 7.18 & 3.35 & 2.04 & 1.02 & 0.94 & & \\
\hline Val 32 & 8.35 & 3.64 & 2.05 & 0.98 & 0.97 & & \\
\hline Val 38 & 7.42 & 3.62 & 1.99 & 1.09 & 1.04 & & \\
\hline Val 50 & 8.42 & 4.71 & 1.92 & 0.86 & 0.85 & & \\
\hline Val 53 & 8.88 & 4.05 & 1.82 & 0.99 & 0.98 & & \\
\hline Val 57 & 8.00 & 4.80 & 2.36 & 0.99 & 0.97 & & \\
\hline Val 66 & 8.22 & 4.43 & 1.67 & 0.74 & 0.61 & & \\
\hline Val 70 & 8.75 & 5.38 & 2.09 & 0.84 & 0.65 & & \\
\hline Val 79 & 8.86 & 3.65 & 2.13 & 1.19 & 0.89 & & \\
\hline \multirow[t]{2}{*}{ Val 82} & 8.48 & 4.71 & 2.24 & 1.31 & 1.19 & & \\
\hline & $\mathrm{H}^{\mathrm{N}}$ & $\mathbf{H}^{a}$ & $\mathrm{H}^{\beta}$ & $\mathbf{H}^{\gamma 2}$ & \multicolumn{2}{|c|}{$\mathrm{H}^{\gamma \prime}, \mathrm{H}^{\gamma^{\prime}}}$, & $\mathrm{H}^{\delta}$ \\
\hline Ile 39 & 8.08 & 2.97 & 1.22 & 0.12 & 0.72 & -1.10 & -0.07 \\
\hline Ile 48 & 8.25 & 4.78 & 1.71 & 0.67 & 1.42 & 0.87 & 0.68 \\
\hline Ile 49 & 7.94 & 4.44 & 1.60 & 0.85 & 1.32 & 1.13 & 0.78 \\
\hline Ile 56 & 8.48 & 4.12 & 1.88 & 0.93 & 1.65 & 1.32 & 0.91 \\
\hline Ile 63 & 7.96 & 3.75 & 1.92 & 0.97 & 1.59 & 1.38 & 1.02 \\
\hline \multirow[t]{2}{*}{ Ile 76} & 9.09 & 4.04 & 2.58 & 1.12 & 1.72 & 1.21 & 0.75 \\
\hline & $\mathbf{H}^{\mathrm{N}}$ & $\mathrm{H}^{\alpha}$ & $\mathrm{H}^{\beta}$ & & & & \\
\hline Ala 14 & 8.11 & 4.34 & 1.41 & & & & \\
\hline Ala 35 & 8.38 & 4.07 & 1.40 & & & & \\
\hline Ala 46 & 7.95 & 4.20 & 1.16 & & & & \\
\hline \multirow[t]{2}{*}{ Ala 77} & 9.50 & 4.69 & 1.45 & & & & \\
\hline & $\mathrm{H}^{\mathrm{N}}$ & $\mathrm{H}^{\alpha}$ & \multicolumn{2}{|c|}{$\mathrm{H}^{\beta^{\prime}}, \mathrm{H}^{\beta \prime \prime}$} & & & \\
\hline Asp 16 & $\mathrm{~N} / \mathrm{A}$ & 4.73 & 2.78 & 2.81 & & & \\
\hline Asp 42 & 7.58 & 4.75 & 3.11 & 3.18 & & & \\
\hline Asp 64 & 8.29 & 4.44 & 2.68 & 2.86 & & & \\
\hline Asp 71 & 8.79 & 4.78 & 2.67 & 3.48 & & & \\
\hline Asp 74 & 8.30 & 4.21 & 2.96 & 3.36 & & & \\
\hline
\end{tabular}




\begin{tabular}{|c|c|c|c|c|c|c|c|c|c|c|}
\hline \multirow[b]{2}{*}{ Asn 11} & \multirow{2}{*}{$\begin{array}{l}\mathbf{H}^{\mathrm{N}} \\
8.53\end{array}$} & \multirow{2}{*}{$\begin{array}{l}\mathrm{H}^{\alpha} \\
4.83\end{array}$} & \multicolumn{2}{|c|}{$H^{\beta}, H^{\beta}$} & \multicolumn{2}{|c|}{$\mathrm{H}^{\delta 2}, \mathrm{H}^{\delta 2 ”}$} & & & & \\
\hline & & & 2.79 & 2.92 & & d) & & & & \\
\hline Asn 19 & 8.53 & 4.83 & 2.79 & 2.92 & & d) & & & & \\
\hline Asn 19 & & 4.41 & 2.97 & 2.99 & 7.03 & 7.68 & & & & \\
\hline \multirow[t]{2}{*}{ Asn 75} & 8.27 & 5.40 & 2.03 & 3.03 & 6.59 & 7.90 & & & & \\
\hline & $\mathrm{H}^{\mathrm{N}}$ & $\mathrm{H}^{\mathrm{a}}$ & \multicolumn{2}{|c|}{$\mathrm{H}^{\beta}, \mathrm{H}^{\beta}$} & & & & & & \\
\hline $\operatorname{Ser}(1,2)^{e)}$ & 8.23 & 4.48 & 3.89 & 3.87 & & & & & & \\
\hline $\operatorname{Ser}(1,2)$ & 8.37 & 4.53 & 3.91 & 3.89 & & & & & & \\
\hline \multirow[t]{2}{*}{ Ser 31} & 8.51 & 5.00 & 4.45 & 4.11 & & & & & & \\
\hline & $\mathrm{H}^{\mathrm{N}}$ & $\mathrm{H}^{a}$ & \multicolumn{2}{|c|}{$\mathrm{H}^{\beta}, \mathrm{H}^{\beta \prime}$} & $\mathrm{H}^{\delta}$ & $\mathbf{H}^{\varepsilon}$ & $\mathrm{H}^{\zeta}$ & & & \\
\hline \multirow[t]{2}{*}{ Phe 69} & 9.02 & 5.71 & 2.89 & 2.64 & 7.28 & 7.29 & 7.11 & & & \\
\hline & $\mathrm{H}^{\mathrm{N}}$ & $\mathrm{H}^{a}$ & \multicolumn{2}{|c|}{$\mathrm{H}^{\beta}, \mathrm{H}^{\beta \prime}$} & $\mathrm{H}^{\delta}$ & $\mathrm{H}^{\varepsilon}$ & & & & \\
\hline \multirow[t]{2}{*}{ Туг 61} & 8.53 & 4.89 & 3.03 & 2.97 & 7.17 & 6.81 & & & & \\
\hline & $\mathbf{H}^{\mathrm{N}}$ & $\mathbf{H}^{a}$ & \multicolumn{2}{|c|}{$H^{\beta}, H^{\beta \prime}$} & $\mathbf{H}^{\delta 1}$ & $\mathrm{H}^{\varepsilon 1}$ & $\mathrm{H}^{\mathrm{t}^{2}}$ & $\mathrm{H}^{n}$ & $\mathrm{H}^{53}$ & $\mathrm{H}^{\mathrm{\varepsilon} 3}$ \\
\hline \multirow[t]{2}{*}{$\operatorname{Trp} 24$} & 8.25 & 5.18 & 3.12 & 2.96 & 7.16 & 10.39 & 7.20 & 6.68 & 6.62 & 7.34 \\
\hline & $\mathbf{H}^{\mathrm{N}}$ & $\mathrm{H}^{\boldsymbol{a}}$ & \multicolumn{2}{|c|}{$H^{\beta}, H^{\beta \prime \prime}$} & & $\mathrm{H}^{\delta 2}$ & $\mathrm{H}^{\varepsilon \iota}$ & & & \\
\hline \multirow[t]{2}{*}{ His 18} & $\mathrm{~N} / \mathrm{A}$ & 4.75 & 3.48 & 2.64 & & 7.35 & 8.65 & & & \\
\hline & $\mathbf{H}^{\mathrm{N}}$ & $\mathbf{H}^{\alpha}$ & \multicolumn{2}{|c|}{$\mathrm{H}^{\beta^{\prime}}, \mathrm{H}^{\beta^{\prime}}$} & \multicolumn{2}{|c|}{$\mathrm{H}^{\gamma}, \mathrm{H}^{\gamma}$} & & & & \\
\hline $\operatorname{Glu}(4,8)^{\mathrm{n}}$ & 8.43 & 4.35 & 2.11 & 1.98 & & & & & & \\
\hline Glu $(4,8)$ & 8.27 & 4.32 & 2.06 & 1.96 & & & & & & \\
\hline Glu 23 & 6.73 & 5.34 & 2.18 & 1.84 & 2.29 & 2.17 & & & & \\
\hline Glu 26 & 10.62 & 4.42 & 2.19 & 2.16 & 2.59 & 2.18 & & & & \\
\hline Glu 33 & 8.25 & 3.98 & 2.06 & 1.98 & 2.43 & 2.05 & & & & \\
\hline Glu 34 & 7.61 & 4.06 & 2.21 & 2.05 & 2.35 & & & & & \\
\hline Glu 45 & 9.28 & 4.46 & 2.12 & 2.08 & 2.49 & 2.13 & & & & \\
\hline \multirow[t]{2}{*}{ Glu 60} & 8.47 & 4.34 & 2.19 & 2.05 & 2.45 & 2.05 & & & & \\
\hline & $\mathbf{H}^{\mathrm{N}}$ & $\mathrm{H}^{\alpha}$ & \multicolumn{2}{|c|}{$\mathrm{H}^{\mathrm{\beta}}, \mathrm{H}^{\mathrm{\beta}}$} & \multicolumn{2}{|c|}{$\mathrm{H}^{\gamma}, \mathbf{H}^{\gamma}$} & \multicolumn{2}{|c|}{$\mathrm{H}^{\varepsilon^{\prime}}, \mathbf{H}^{\varepsilon^{\prime}}$} & & \\
\hline Gln 41 & 7.30 & 4.15 & 2.32 & 2.22 & 2.52 & 2.48 & g) & & & \\
\hline Gln 47 & 8.87 & 4.42 & 1.92 & 1.84 & 2.32 & 2.17 & g) & & & \\
\hline \multirow[t]{2}{*}{ Gln 78} & 7.32 & 4.78 & 2.15 & 1.99 & 2.34 & 2.30 & g) & & & \\
\hline & & $\mathrm{H}^{a}$ & \multicolumn{2}{|c|}{$\mathrm{H}^{\beta^{\prime}}, \mathrm{H}^{\beta^{\prime}}$} & \multicolumn{2}{|c|}{$\mathrm{H}^{\gamma}, \mathrm{H}^{\gamma}$} & \multicolumn{2}{|c|}{$\mathbf{H}^{\delta^{\prime}}, \mathbf{H}^{\delta^{\natural}}$} & & \\
\hline Pro 7 & & 4.44 & 2.31 & 1.93 & 2.06 & 2.03 & 3.65 & 3.84 & & \\
\hline Pro 25 & & 4.68 & 2.49 & 1.97 & 2.29 & 2.08 & 3.31 & 3.92 & & \\
\hline Pro 44 & & 4.37 & 2.38 & 2.12 & 2.09 & & 3.77 & 3.45 & & \\
\hline Pro 52 & & 4.83 & 2.50 & 1.83 & 2.12 & & 3.89 & 3.67 & & \\
\hline Pro 80 & & 4.82 & 2.25 & 2.10 & 1.86 & 1.86 & 4.33 & 4.07 & & \\
\hline
\end{tabular}




\begin{tabular}{|c|c|c|c|c|c|c|c|c|}
\hline \multirow[b]{2}{*}{ Leu 20} & \multirow{2}{*}{$\begin{array}{l}\mathrm{H}^{\mathrm{N}} \\
\mathrm{N} / \mathrm{A}\end{array}$} & \multirow{2}{*}{$\begin{array}{l}\mathrm{H}^{\mathrm{a}} \\
4.36\end{array}$} & \multicolumn{2}{|c|}{$H^{\beta \prime}, H^{\beta \prime \prime}$} & \multirow{2}{*}{$\begin{array}{l}H^{\gamma} \\
1.65\end{array}$} & \multicolumn{2}{|c|}{$\mathrm{H}^{\delta^{\prime}}, \mathrm{H}^{\delta^{\prime \prime}}$} & \\
\hline & & & 1.63 & 1.60 & & 0.98 & 0.94 & \\
\hline Leu 27 & 7.88 & 4.45 & 1.95 & 1.76 & 1.57 & 0.94 & 0.87 & \\
\hline Leu 40 & 7.89 & 4.11 & 1.78 & 1.38 & 1.50 & 0.67 & 0.65 & \\
\hline Leu 51 & 9.09 & 5.02 & 1.37 & 1.23 & 1.32 & 0.82 & 0.58 & \\
\hline Leu 68 & 9.06 & 4.80 & 1.79 & 0.97 & 1.68 & 0.95 & 0.85 & \\
\hline \multirow[t]{2}{*}{ Leu 73} & 8.04 & 4.44 & 1.83 & 1.75 & 1.81 & 0.87 & 0.87 & \\
\hline & $\mathrm{H}^{\mathrm{N}}$ & $\mathrm{H}^{\alpha}$ & \multicolumn{2}{|c|}{$\mathrm{H}^{\beta^{\prime}}, \mathrm{H}^{\beta}}$, & & & & \\
\hline \multirow[t]{2}{*}{ Met 59} & 8.24 & 4.23 & 1.57 & 1.50 & & & & \\
\hline & $\mathrm{H}^{\mathrm{N}}$ & $\mathbf{H}^{\mathfrak{a}}$ & \multicolumn{2}{|c|}{$H^{\beta}, H^{\beta^{\prime \prime}}$} & \multicolumn{2}{|c|}{$\mathrm{H}^{\gamma}, \mathrm{H}^{\gamma^{\prime \prime}}$} & $\mathrm{H}^{\delta^{\prime}}, \mathrm{H}^{\delta} "$ & $\mathbf{H}^{\varepsilon}$ \\
\hline $\operatorname{Arg} 17$ & $\mathrm{~N} / \mathrm{A}$ & 4.62 & 1.85 & 1.74 & & & & \\
\hline $\operatorname{Arg} 62$ & 8.80 & 4.54 & 1.76 & 1.52 & 1.47 & 1.58 & 3.15 & 7.89 \\
\hline $\operatorname{Arg} 65$ & 7.26 & 5.02 & 2.23 & 1.25 & & & & \\
\hline $\operatorname{Arg} 67$ & $8.98^{\mathrm{h})}$ & 4.68 & 1.84 & N/A & & & & \\
\hline \multirow[t]{2}{*}{ Arg 81} & 9.25 & 5.72 & 2.10 & 2.00 & & & & \\
\hline & $\mathrm{H}^{\mathrm{N}}$ & $\mathrm{H}^{a}$ & \multicolumn{2}{|c|}{$H^{\beta}, H^{\beta \prime \prime}$} & & & & \\
\hline Lys 5 & 8.24 & 4.33 & 1.83 & 1.75 & & & & \\
\hline Lys 6 & 7.83 & 4.31 & 1.89 & 1.77 & & & & \\
\hline Lys 21 & N/A & 4.62 & 2.30 & 1.99 & & & & \\
\hline Lys 30 & $7.86^{\mathrm{h})}$ & 4.62 & 2.09 & 1.92 & & & & \\
\hline Lys 36 & 8.48 & 3.50 & 1.75 & 1.73 & & & & \\
\hline Lys 37 & 6.98 & 3.88 & 1.92 & 1.92 & & & & \\
\hline Lys 43 & 9.08 & 4.78 & 2.12 & 1.99 & & & & \\
\hline Lys 72 & 8.15 & 4.21 & 1.94 & 1.94 & & & & \\
\hline \multicolumn{9}{|c|}{ 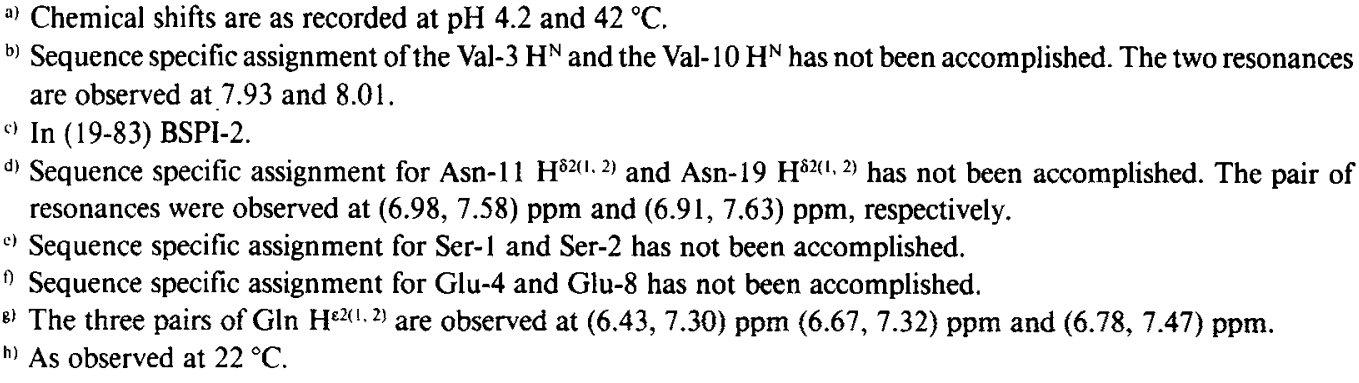 } \\
\hline
\end{tabular}

between protons having very similar chemical shifts. The $\mathrm{H}^{\beta}-\mathrm{H}^{\gamma 2(1,2,3)}$ of the three threonines in (19-83)BSPI-2 were subsequently identified both in the COSY and in the $2 \mathrm{Q}$ spectrum. Note, however, that the $\mathrm{H}^{\beta}-\mathrm{H}^{\gamma 2(1.2 .3)}$ cross peak at (4.59, 1.31) ppm in Figure 2 has been eliminated by water resonance suppression. The Thr- 12 spin system was likewise identified in the COSY and double quantum spectrum of the intact BSPI-2, being the only additional threonine in the $\mathrm{N}$-terminal part of the protein (Figure 3 ).

\subsubsection{Valines}

The (19-83)BSPI-2 contains 10 valines (see Table I) and this residue type therefore is the most abundant in the protein. The typical $\mathrm{H}^{\beta}-\mathrm{H}^{1(1,2,3)}, \mathbf{H}^{\beta}-\mathrm{H}^{\gamma(1,2,3)}$ cross peaks are the "fingerprints" of this residue, they are found, however, in the same region of the spectrum as the $\mathrm{H}^{\gamma}-\mathrm{H}^{\delta 1(1,2,3)}, \mathrm{H}^{\gamma}-\mathrm{H}^{\delta 2(1,2,3)}$ cross peaks of leucines of which the (19-83)BSPI-2 have six. Obviously, the distinction between the valine and leucine methyl group resonances can be 


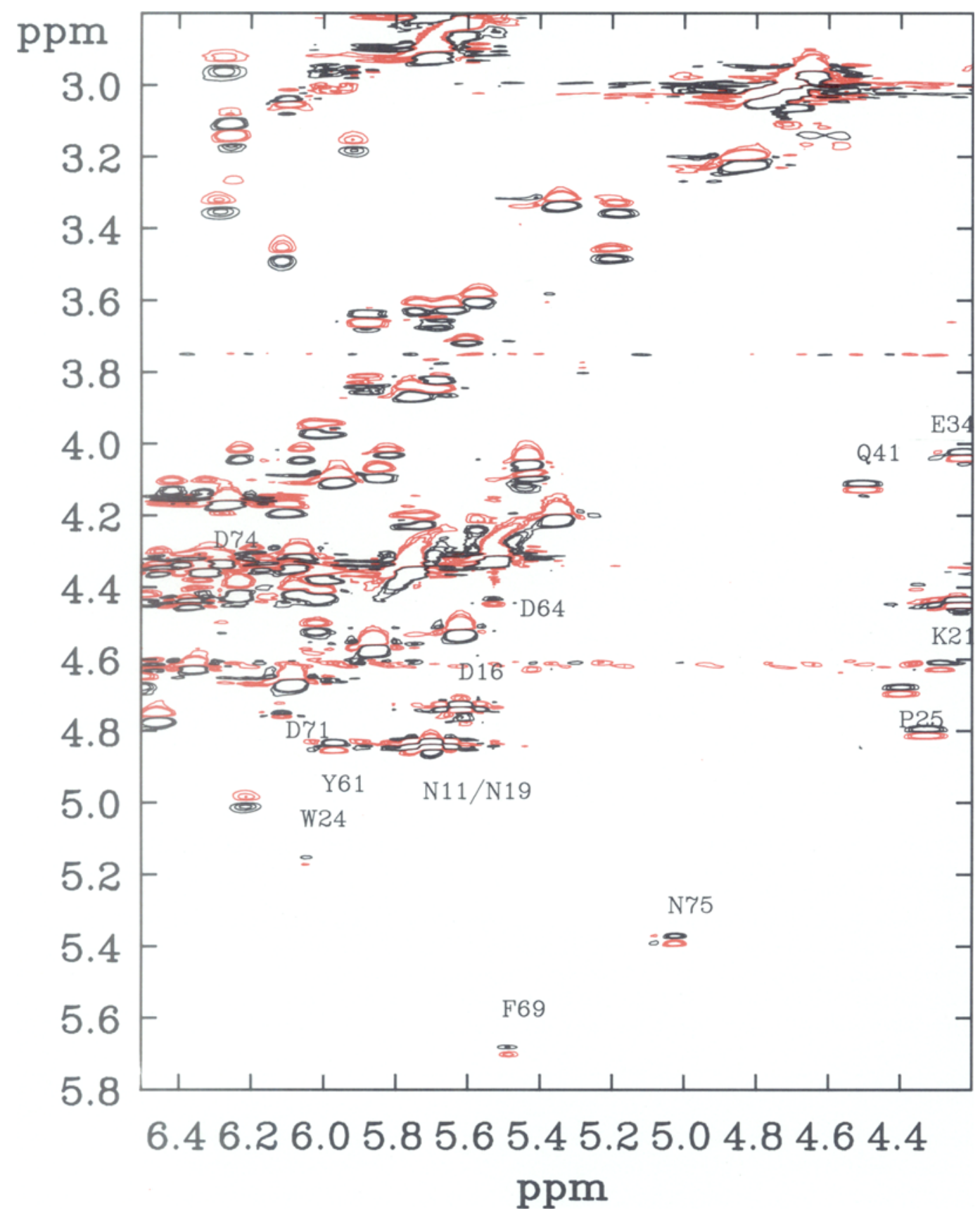

Figure 3. ' $\mathrm{H}-{ }^{\prime} \mathrm{H}$ Double quantum spectrum of BSPI-2 $\left(0.01 \mathrm{M}, \mathrm{pH} 4.2,37{ }^{\circ} \mathrm{C} 99.96 \%{ }^{2} \mathrm{H}_{2} \mathrm{O}\right)$ mixing time $0.036 \mathrm{~s}$. The spectrum is labelled as in Figure 2. The assignment of the indirect $\mathrm{H}^{\beta 1}-\mathrm{H}^{\beta 2}$ coherence effects are indicated.

made only when the complete identification of the valine spin systems is achieved. The $\mathrm{H}^{\alpha}-\mathrm{H}^{\beta}$ cross peaks of the valines are shown in Figure 2, however, the level of contouring is not sufficiently low to show the weak $\mathrm{H}^{\mathrm{a}}$ - $\mathrm{H}^{\beta}$ cross peaks of Val-52 at $(4.80,2.36) \mathrm{ppm}$ and Val-70 


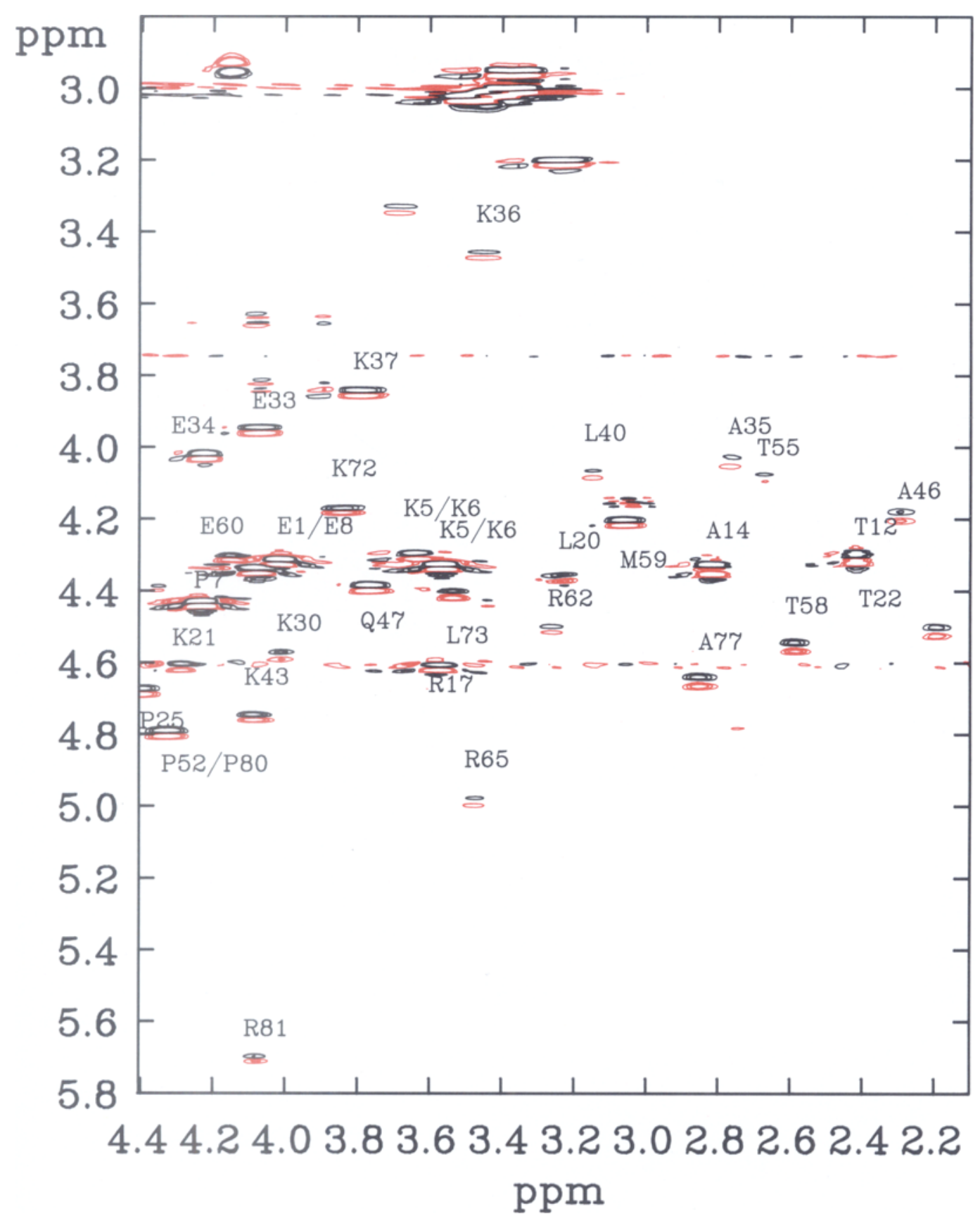

at $(5.35,2.09) \mathrm{ppm}$. In Figure 4 is shown the region of the COSY spectrum where the $\mathrm{H}^{\beta}-\mathrm{H}^{\mathrm{r}(1.2 .3)}, \mathrm{H}^{\beta}-\mathrm{H}^{\gamma 2(1,2.3)}$ cross peaks of the valines occur. Additional support for the valine assignments was found in the relayed COSY spectrum, where relayed effects respectively from each of the $\mathrm{H}^{a}$ protons to the $\gamma$-methyl group protons were observed. A summary of the chemical shifts of the valine protons is given in Table I. The additional two valines in the 


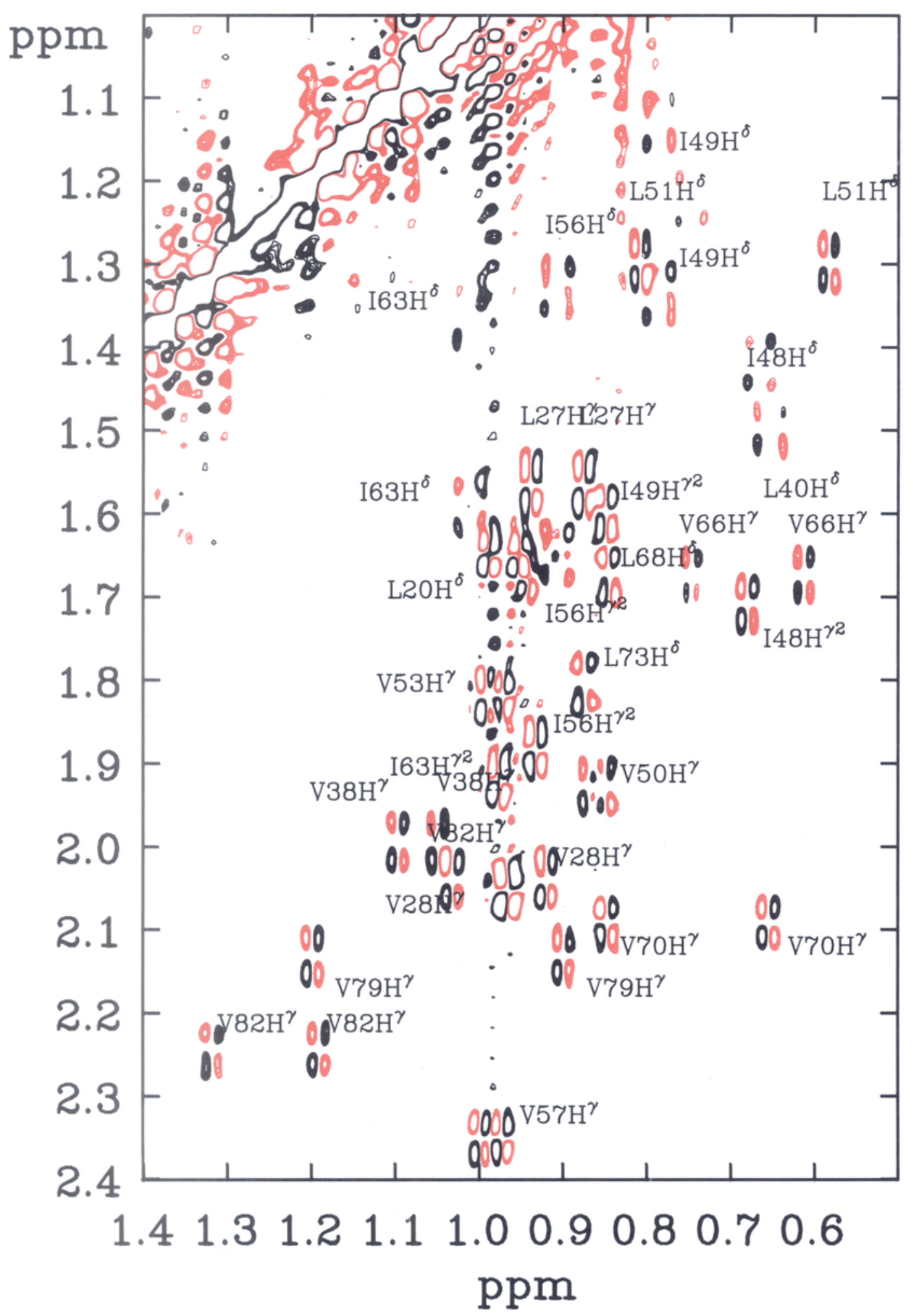


Figure 4. ' $\mathrm{H}-{ }^{\prime} \mathrm{H}$ COSY spectrum of (19-83)BSPI-2 $\left(0.01 \mathrm{M}, \mathrm{pH} 4.2,90 \% / 10 \%{ }^{1} \mathrm{H}_{2} \mathrm{O} /{ }^{2} \mathrm{H}_{2} \mathrm{O}, 42{ }^{\circ} \mathrm{C}\right)$. The region of the spectrum shown displays the methyl group cross peaks of the valines, leucines and isoleucines.

spectrum of the intact protein were observed to have identical chemical shift values for all the side chain proton resonances, however, the two $\mathrm{H}^{\mathrm{N}}$ signals had slightly different chemical shifts, see Table I.

\subsubsection{Isoleucines}

The two characteristic features of the isoleucine spin systems are the $\mathrm{H}^{\alpha}-\mathrm{H}^{\beta}-\mathrm{H}^{\gamma 2(1,2,3)}$ and the $\mathrm{H}^{\gamma 11}-\mathrm{H}^{\delta(1,2,3)}-\mathrm{H}^{\gamma / 2}$ tracks of cross peaks. The inhibitor contains six isoleucines, Ile-39, Ile-48, Ile-49, Ile-56, Ile-63 and Ile-76. Each of the six $\mathrm{H}^{\alpha}-\mathrm{H}^{\beta}$ cross peaks are seen in Figure 2, the Ile- $63\left(\mathrm{H}^{\alpha}-\mathrm{H}^{\beta}\right)$ cross peak is, however, of rather low intensity. The six $\mathrm{H}^{\beta}-\mathrm{H}^{\gamma^{2(1,2,3)}}$ cross peaks were clearly distinguished from the $\mathrm{H}^{\alpha}-\mathrm{H}^{\beta(1,2,3)}$ and $\mathrm{H}^{\beta}-\mathrm{H}^{\gamma 2(1,2,3)}$ cross peaks of alanines and threonines, respectively, due to the large difference in chemical shifts between the $\mathrm{H}^{\beta}$ resonance of isoleucine and the $\mathrm{H}^{\alpha}$ and the $\mathrm{H}^{\beta}$ of these two amino acid types. Additional evidence for the $\mathrm{H}^{\alpha}-\mathrm{H}^{\mathrm{B}}-\mathrm{H}^{2(1,2,3)}$ assignments was seen in the relayed COSY spectrum where the $\mathrm{H}^{\mathrm{a}}-\mathrm{H}^{2(1,2,3)}$ effects were all clearly observed.

The triplet of the $H^{\delta(1,2,3)}$ resonances of the isoleucines was clearly observed in the anti-phase COSY cross peaks with 1:2 rectangular pattern of $\left(\mathrm{H}^{\gamma 11}, \mathrm{H}^{\gamma / 2}\right)-\mathrm{H}^{\delta(1,2,3)}$ coupling, hence the six pairs of this type of cross peaks were immediately assigned to isoleucines. The remaining identification of the respective $\mathrm{H}^{\beta}-\mathrm{H}^{\mathrm{x}(1,2)}$ cross peak in the COSY spectrum to complete the assignments of these six spin systems was straightforward given that the primary identification of the two parts of the six spin systems had narrowed the cross peak search. It should be noticed that two isoleucines though are having quite strongly shifted resonances compared to the basis shift of these in model peptides. These are Ile-39 and Ile-76 which as far as the $\mathrm{H}^{\beta}$ chemical shifts are concerned are shifted respectively $0.7 \mathrm{ppm}$ upand downfield, and more dramaticly so is the Ile-39 $\mathrm{H}^{\mathrm{r}(1 \text { or 2) }}$ shifted more than $2.0 \mathrm{ppm}$ to -1.10 ppm.

\subsubsection{Aromatic residues}

The serine proteinase inhibitor contains only one of each of the aromatic residues tryptophan, tyrosine and phenylalanine. The identification of $\mathrm{H}^{\varepsilon l}$ and the $\mathrm{H}^{\delta 1}$ resonances of the tryptophan was accomplished using on the characteristic chemical shift of the $\mathrm{H}^{\varepsilon 1}$ and the coupling seen in the COSY spectra between these. Also the identification of the benzenoid protons of the tryptophan ring was obtained using the multiplet information observed in the antiphase cross peaks in the COSY spectrum. The distinction between the $\mathrm{H}^{\mathrm{b}}$ and the $\mathrm{H}^{\mathrm{s} 3}$ doublets was established by the observation of the NOE effect between the $\mathrm{H}^{\mathrm{s} 1}$ and the $\mathrm{H}^{\mathrm{82}}$. Likewise, the assignment of the $\mathrm{H}^{\delta(1,2)}-\mathrm{H}^{\mathrm{e}(1,2)}$ cross peak of the tyrosyl residue was straightforward and the identification of the $\mathrm{H}^{\text {(11,2) }}$ chemical shifts was obtained from $\mathrm{pH}$-titrations at high $\mathrm{pH}$ in which these protons were observed to have relatively

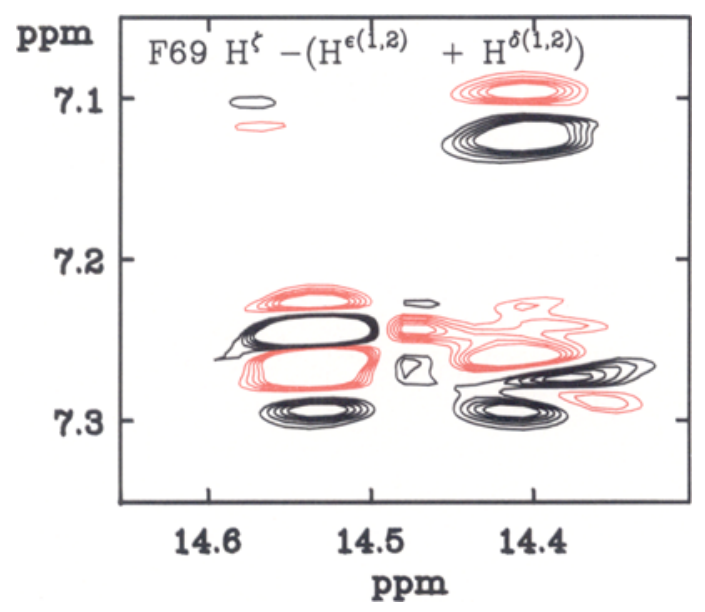

Figure 5. Double quantum spectrum (mixing time $0.036 \mathrm{~s}$ ) of (19-83)BSPI-2, (0.01 M, pH $4.2099 .97 \%$ ${ }^{2} \mathrm{H}_{2} \mathrm{O} 37^{\circ} \mathrm{C}$ ). The spin system cross peaks of the phenyl group of Phe-69. The $\mathrm{H}^{\delta}(1,2)-\mathrm{H}^{\mathrm{z}}(1,2) 2 \mathrm{Q}$ coherence detected at the $\mathrm{H}^{\natural}$ chemical shift was used to identify the $\mathrm{H}^{\delta}$ chemical shift, which by coincidence is very close to the chemical shift of the $\mathrm{H}^{\mathrm{s}}$. 


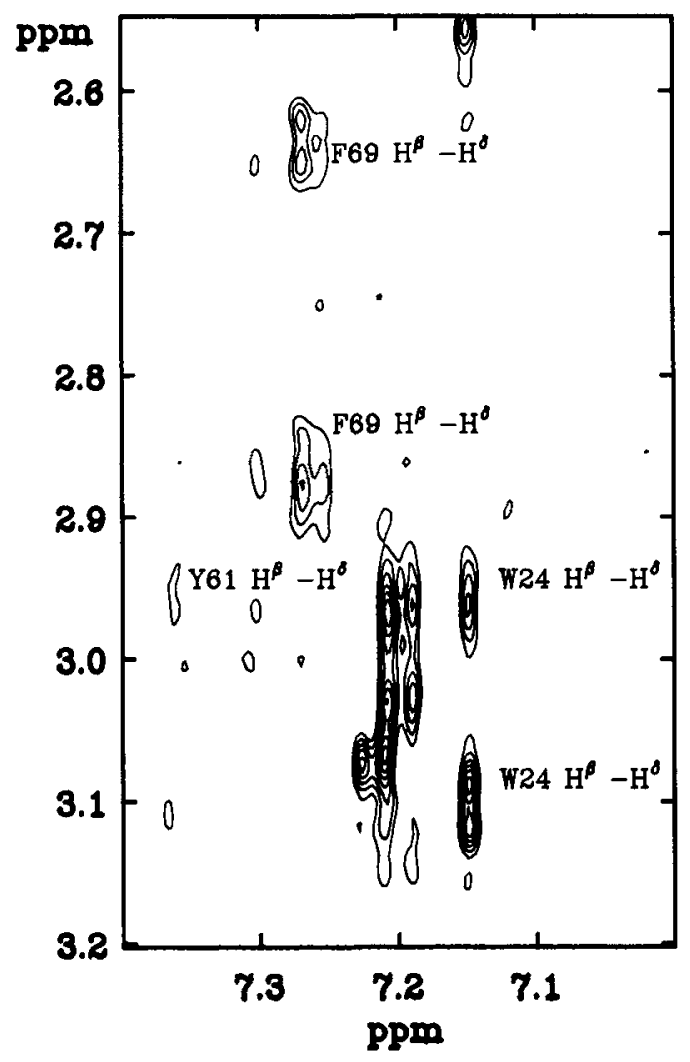

Figure 6. 'H NOESY spectrum of (19-83)BSPI-2 recorded with a mixing time of $0.20 \mathrm{~s},(0.01 \mathrm{M}$, $90 \% / 10 \%{ }^{1} \mathrm{H}_{2} \mathrm{O} /{ }^{2} \mathrm{H}_{2} \mathrm{O}, \mathrm{pH} 4.2,42^{\circ} \mathrm{C}$ ). The cross peaks shown are the $\mathrm{H}^{\delta}-\mathrm{H}^{\beta}$ cross peaks of the aromatic residues, Trp-24, Tyr-61 and Phe-69.

large upfield shifts as expected due to the ionization of the hydroxyl group. The cross peaks of the aromatic protons of the phenylalanine were not all observed in the COSY spectra and only examiniation of the $2 \mathrm{QS}$ spectrum of this residue revealed that the $\mathrm{H}^{\delta(1,2)}$ and the $\mathrm{H}^{e(1,2)}$ resonances were so close in chemical shifts that they were not distinguishable in the COSY spectrum. In Figure 5 is shown the cross peak due to the $2 \mathrm{Q}$ coherence of the $\mathrm{H}^{8(1,2)}$ and $\mathrm{H}^{\varepsilon(1,2)}$ at the chemical shift position of the $\mathrm{H}^{\zeta}$.

The completion of the assignment of these three aromatic residues was accomplished using the NOE effects expected between the $\mathrm{H}^{\delta 1}$ and the two $\mathrm{H}^{\beta}$ 's of the respective amino acids $(6$, 45), see Figure 6.

\subsubsection{The non-aromatic $A M X$ systems}

The (19-83)BSPI- 2 contains 2 asparagines one of which is the $\mathrm{N}$-terminal residue, 4 aspartic acids and 1 serine, all AMX spin systems. The AMX spin system with two low field $\mathrm{H}^{\beta}$ resonances at 4.45 and 4.11 , respectively, was assigned to the only serine in the molecule. The Ser- 1 and Ser-2 spin systems in the intact BSPI-2 were indentified in the COSY spectrum of BSPI- 2 using the criteria that the $\mathrm{H}^{\beta}$ resonances of serine are normally at low field, however, lacking the sequential NOE's in this region, sequence specific assignments were not accomplished for these two spin systems. The four aspartic acid residues were identified using a series of COSY spectra recorded at $\mathrm{pH}$ values in the $\mathrm{pH}$ region between $\mathrm{pH} 3$ and $\mathrm{pH} 7$ where the aspartic acid normally has its $\mathrm{pK}$. Three of the AMX $\mathrm{H}^{\beta}-\mathrm{H}^{\beta}$ cross peaks showed the typical upfield shift with increasing $\mathrm{pH}$, Figure 7 , however, one $\mathrm{H}^{\beta}-\mathrm{H}^{\beta}$ cross peak which later in the sequential assignment procedure was shown to be the Asp-42 $\mathrm{H}^{\beta}-\mathrm{H}^{\beta}$ cross peak showed an abnormal downfield shift for one of the $\mathrm{H}^{\beta 3}$-resonance. This observation could otherwise have indicated that this residue was an asparagine rather than an aspartic acid as determined in the chemical amino acid sequence determination. However, the number of signals of nitrogen bound $\mathrm{H}^{\ell}$ and $\mathrm{H}^{\delta}$ from glutamines and asparagines in the COSY spectrum is in agreement with the expected number of 2 asparagines and 3 glutamines excluding the possibility that Asp42 should be changed to asparagine in the amino acid sequence of the (19-83)BSPI-2.

The remaining two AMX systems of asparagine were subsequently assigned, one of these were of the N-terminal Asn-19 for which the $\mathrm{H}^{\alpha}$ was found at $4.42 \mathrm{ppm}$. In the intact BSPI-2 the $\mathrm{H}^{\mathrm{a}}$ of Asn-19 shifts to $4.83 \mathrm{ppm}$ as expected, and is found in precisely the same position as that of the Asn-11, Figure 3. The $\mathrm{H}^{\beta}-\mathrm{H}^{\beta}$ cross peak in the $2 \mathrm{Q}$ spectrum at the chemical shift position of this $\mathrm{H}^{\alpha}$ has a cross peak intensity corresponding to two $\mathrm{H}^{\beta}-\mathrm{H}^{\beta}$ cross peaks, and for this reason the resonances of the two Asn-residues in the N-terminal peptide are believed to have identical chemical shifts, as far as the $\mathrm{H}^{N}, \mathrm{H}^{\alpha}, \mathrm{H}^{\beta 1}$, and $\mathrm{H}^{\beta 2}$ are concerned. The cross peaks of the two pairs of $\mathrm{H}^{82}$ for these two 


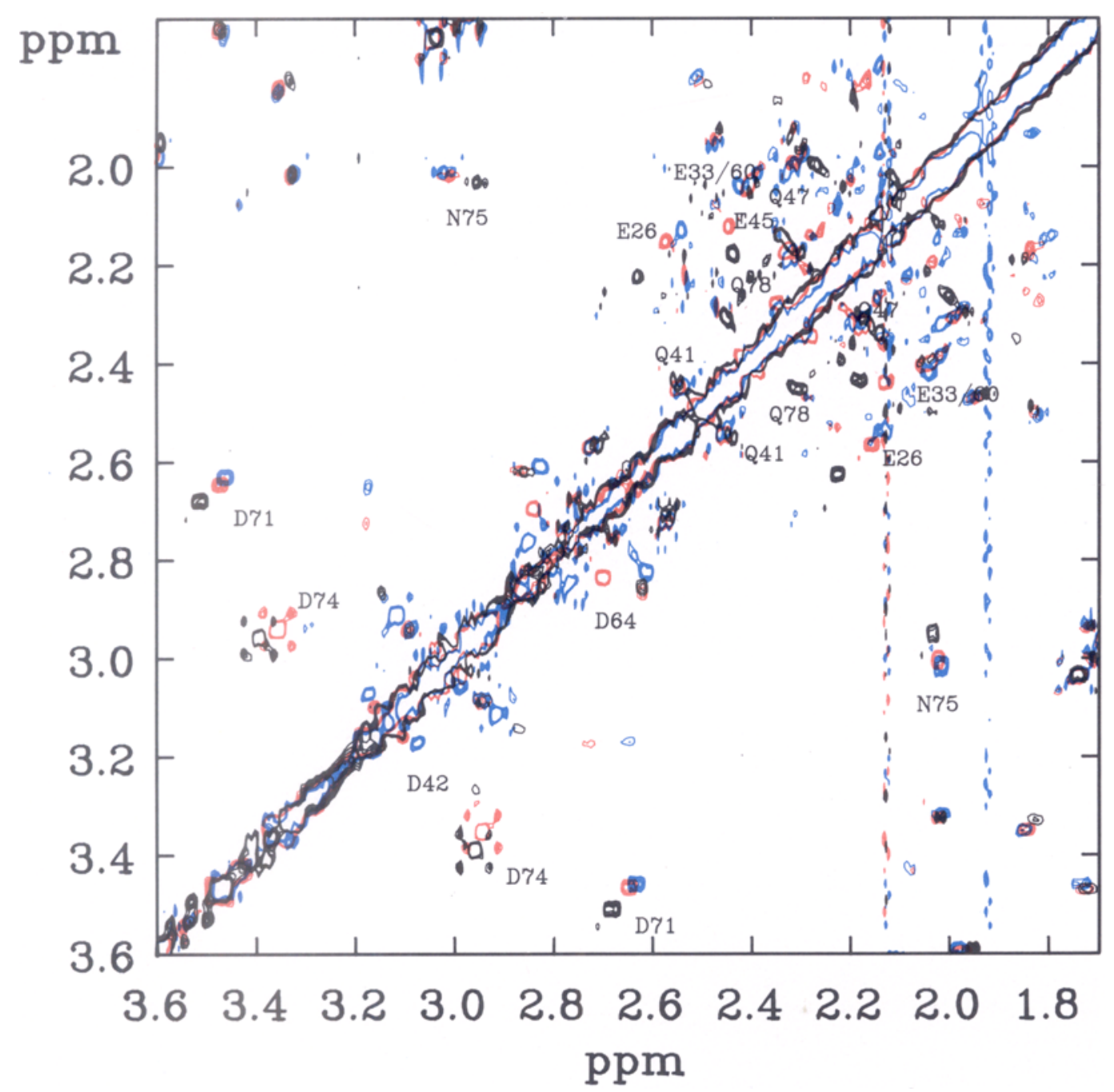

Figure 7. ' $\mathrm{H}-{ }^{-} \mathrm{H}$ phase sensitive COSY spectra of (19-83)BSPI-2, $\left(0.01 \mathrm{M}, 90 \% / 10 \%{ }^{1} \mathrm{H}_{2} \mathrm{O} /{ }^{2} \mathrm{H}_{2} \mathrm{O} 35^{\circ} \mathrm{C}\right)$. The three spectra shown were recorded at $\mathrm{pH} 3.28$ (black), 4.20 (red) and 6.45 (blue). The cross peaks whose chemical shifts are strongly influenced by the $\mathrm{pH}$ are the $\mathrm{H}^{\gamma}-\mathrm{H}^{\gamma}$ cross peaks of glutamic acid, and the $\mathrm{H}^{\beta} \cdot \mathrm{H}^{\beta}$ cross peaks of aspartic acid.

residues are seen at four separate chemical shifts at 7.58,6.89 and 7.63,6.91 but these have not been assigned with respect to sequence. The resonances of Asp-16 in the $\mathrm{N}$-terminal part of BSPI- 2 were identified, by their pH-dependence. The remaining His-18 AMX system was identified on the basis of its chemical shifts in model peptides $(10,54)$.

\subsubsection{The sequential assignment}

The sequential assignment procedure which has been extensively described by WÜTHRICH and co-workers $(54,57)$ employs the nuclear Overhauser effect between hydrogens of neighbouring residues in the amino acid sequence and the amino acid sequence determined by chemical methods to obtain sequence specific assignment of the NMR spectrum of a protein. The 
Table II. Sequential assignment of the (19-83)BSPI-2 NOESY spectrum

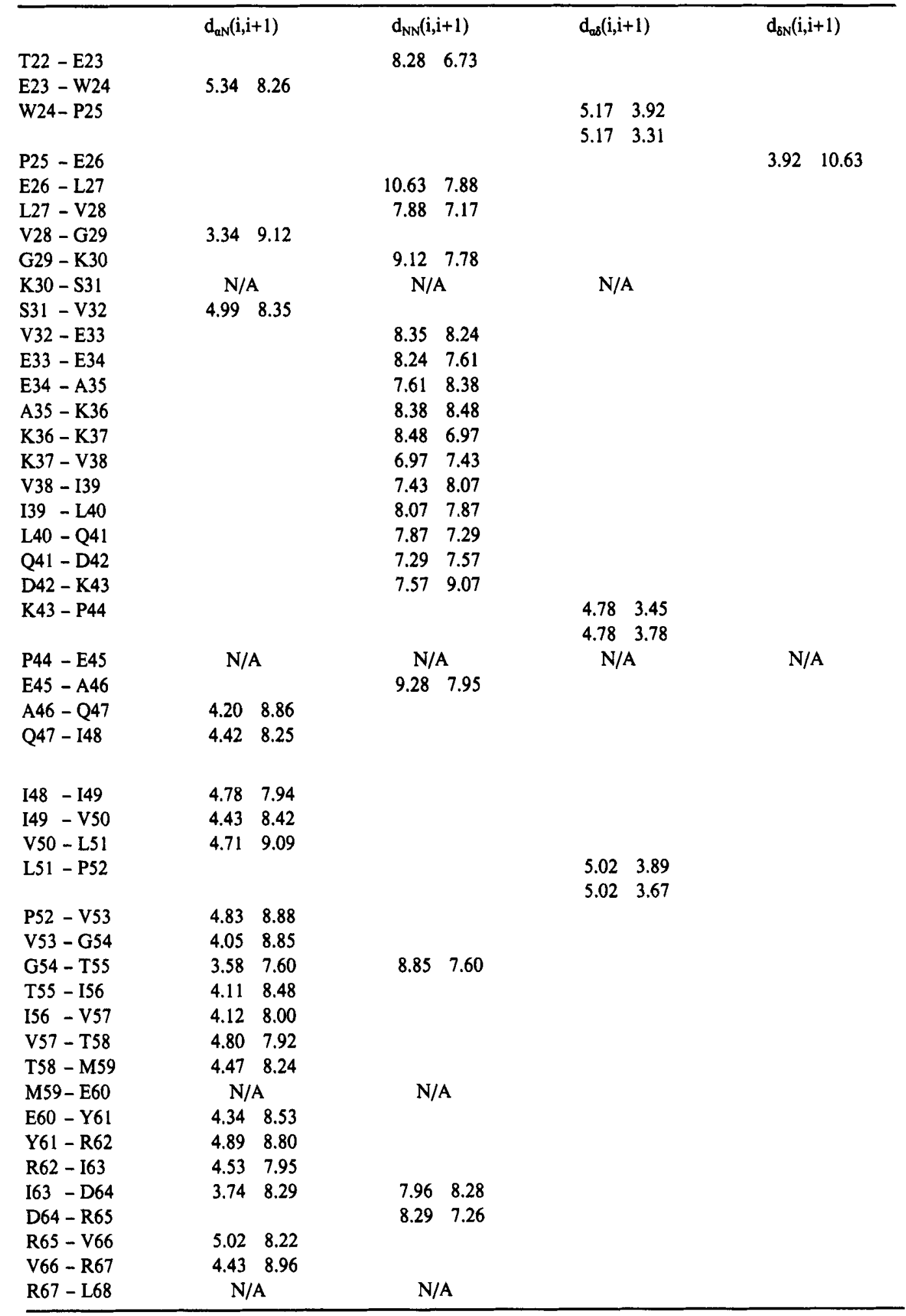




\begin{tabular}{|c|c|c|c|c|}
\hline \multirow[b]{2}{*}{ L68 - F69 } & \multicolumn{2}{|c|}{$d_{a N}(i, i+1)$} & $\mathrm{d}_{\mathrm{NN}}(\mathrm{i}, \mathrm{i}+1)$ & $d_{a \delta}(i, i+1)$ \\
\hline & 4.80 & 9.02 & & \\
\hline$F 69-V 70$ & 5.71 & 8.75 & & \\
\hline V70 - D71 & 5.38 & 8.79 & & \\
\hline D $71-K 72$ & 4.78 & 8.15 & & \\
\hline K $72-L 73$ & & & $8.15 \quad 8.04$ & \\
\hline L73 - D74 & & & $8.04 \quad 8.29$ & \\
\hline D74 - N75 & 4.21 & 8.27 & & \\
\hline N75 - I76 & 5.40 & 9.09 & & \\
\hline $\mathrm{I} 76-\mathrm{A} 77$ & 4.04 & 9.50 & & \\
\hline A77 - Q78 & & & $9.50 \quad 7.32$ & \\
\hline Q78 - V79 & 4.78 & 8.86 & & \\
\hline \multirow[t]{2}{*}{ V79 - P80 } & & & & $3.65 \quad 4.34$ \\
\hline & & & & 3.654 .08 \\
\hline P80 - R81 & 4.82 & 9.25 & & \\
\hline R81 - V82 & 5.72 & 8.48 & & \\
\hline V82 - G83 & 4.71 & 8.80 & & \\
\hline
\end{tabular}

typical sequential NOE's are of the type $d_{a N}(i, i+1)$ and $d_{N N}(i, i+1)(55)$, however, other such as the $d_{p N}(i, i+1)$, the $d_{a N}(i, i+3)$, the $\mathrm{d}_{\mathrm{aN}}(\mathrm{i}, \mathrm{i}+4)$ and the $\mathrm{d}_{\mathrm{NN}}(\mathrm{i}, \mathrm{i}+2)$ are useful types of sequential NOE's in the sequential assignment method. For sequences involving prolines that have no amide hydrogen the $d_{a \delta}(i, i+1)$ can be used. The sequential NOE's observed in the NOESY spectrum of the (19-83)BSPI-2 are listed in Table II and in Figure 8, Figure 9, and Figure 10 are shown the three regions of the NOESY spectrum of (19-83)BSPI-2, respectivly, where the $d_{N N}(i, i+1)$, the $d_{a N}(i, i+1)$, and the $\mathrm{d}_{a \delta}(\mathrm{i}, \mathrm{i}+1)$ are found.

The sequential assignment was based on the initial identification of the spin systems of the 11 amino acid types described previously. In Figure 11 the sequence is listed showing the positions of these amino acids in the sequence. Four of the amino acids occur only once in the sequence, these are Trp-24, Ser-31, Tyr-61 and Phe-69, thus when identified these spin systems were unambiguously assigned. The presence of pairs of neighbouring amino acid residues, which consist of one or two of the 11 amino acids initially identified, and which are unique in occurring only once in the sequence are shown in Figure 11. The four unambiguously assigned spin systems as well as the unique pairs of neighbouring amino acids have been the fixed points for the sequential assignment process. Throughout the sequence the positions of amino acids of the types, which have not been identified initially, form gaps no longer than three contiguous positions.

In six cases the sequential NOE from one residue to the subsequent was not observed in the NOESY spectrum of (19-83)BSPI-2, Table II. Two cases involve the Lys-30 and the Arg-67 for which the $\mathrm{H}^{a}$ resonance is eliminated by the irradiation at the frequency of the water resonance and one case involve the Pro-44 in which neither the $d_{a N}$ (Pro-44, Glu-45) nor the two $d_{\delta \mathrm{N}}$ (Pro-44, Glu-45) are observed which could be expected in case the Pro-44 was in the trans conformation (54), neither is the $d_{a a}$ (Pro-44, Glu-45) observed which could have been expected in case Pro-44 had been in the cis-conformation. Finally, a sequential connectivity between the Met-59 and Glu-60 was not observed in the NOESY spectrum. The peptide bond between these two residues in the active site of the inhibitor, and the lack of a sequential NOE in this case might be due to a large degree of flexibility around this bond which reduces the size of the possible sequential NOE's over the 


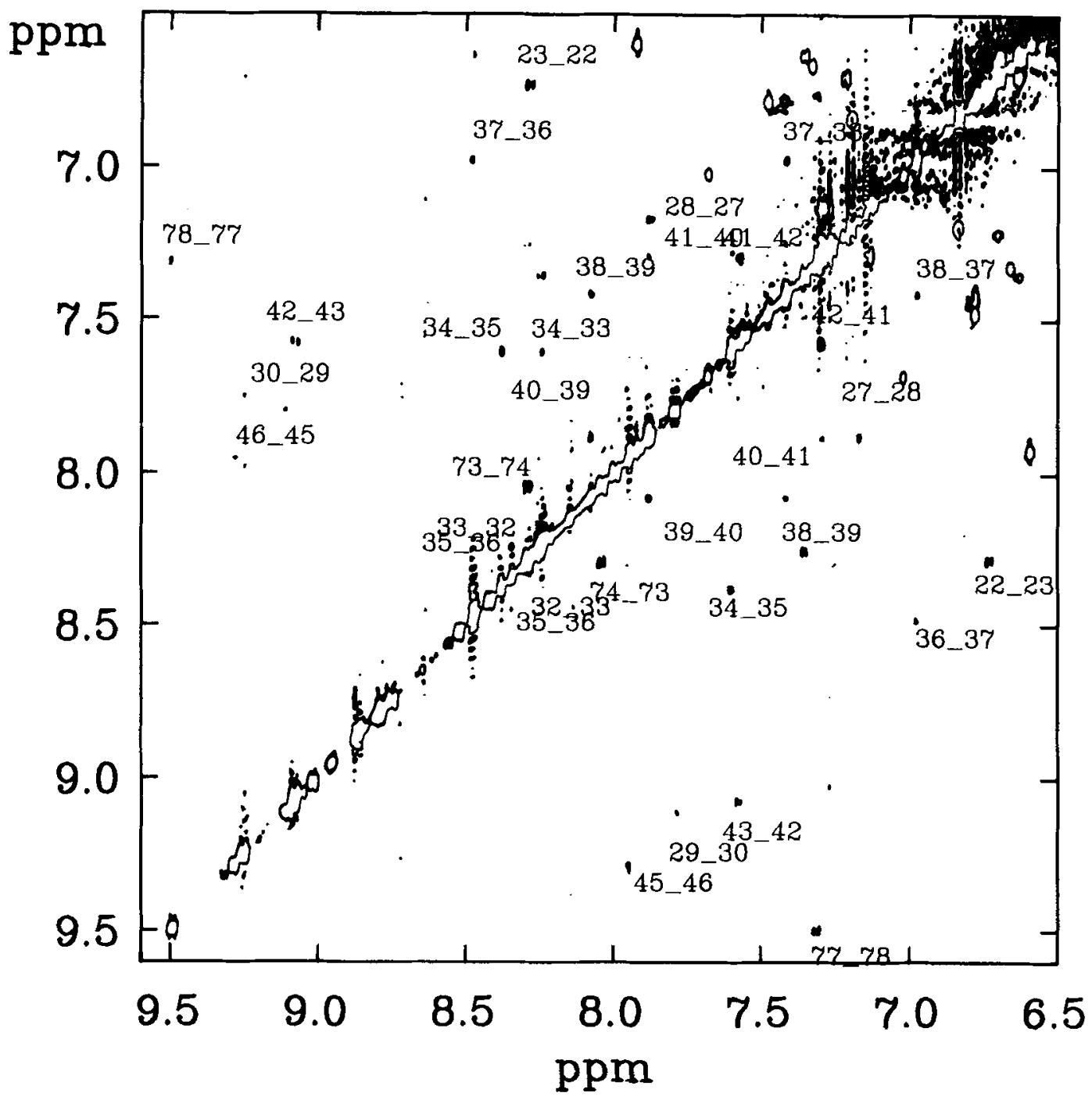

Figure 8. 'H-NOESY spectrum of (19-83)BSPI-2 recorded with a mixing time of $0.20 \mathrm{~s}$. The region shown is the $d_{N N}$ region. The labelling of the $d_{N N}(i, i+1)$ cross peaks is so that the first sequence position is that of the chemical shift of the $\mathrm{H}^{\mathrm{N}}$ in the $\omega_{1}$-direction and the second of the $\omega_{2}$-direction.

peptide bond connecting these two residues so much that it is not observed in NOESY spectra recorded with the mixing time of $0.20 \mathrm{~s}$ applied. Alternatively, an explanation for this could be that the amide exchange of the Glu- $60 \mathrm{H}^{\mathrm{N}}$ is so fast that saturation transfer from the $\mathrm{H}_{2} \mathrm{O}$ saturation pulse is reducing the intensity of this resonance so much that NOE's involving this proton become very small. Finally, in case of the three $\mathrm{N}$-terminal residues of the (19-83)BSPI-2 no sequential NOE's were observed. For the Leu-20 $\mathrm{H}^{\mathrm{N}}$ this is most likely because this peptide hydrogen is in fast exhange with solvent. In the COSY spectrum recorded at $22^{\circ} \mathrm{C}$ the $\mathrm{H}^{\mathrm{N}}-\mathrm{H}^{a}$ cross peak of Leu- 20 is clearly observed, however, at higher temperatures this cross peak disappears. This observation is in agreement with the explanation that solvent exchange in combination with water resonance suppression eliminates NOE's to this hydrogen. For Lys-21 the 
absence of NOE's is due to the $\mathrm{H}^{\alpha}$ resonance of this residue being close to the water resonance. In case of the intact BSPI-2 no sequential NOE's were observed between any of the additional 18 amino acid residues in the NOESY spectra recorded and sequential assignment was therefore not possible in this end of the molecule. The use of longer mixing times than $0.30 \mathrm{~s}$ and lower temperatures might solve this problem, but such experiments have so far not been done.

\subsubsection{Glutamic acid and glutamine}

The spin systems of the six glutamic acids in the (19-83)BSPI-2 were identified as follows. The $\mathrm{H}^{\mathrm{N}}, \mathrm{H}^{\alpha}, \mathrm{H}^{\beta^{\prime}}, \mathrm{H}^{\beta^{\prime \prime}}$ resonances were identified from the COSY and the $2 \mathrm{Q}$ spectra, as described previously. The identification of the $\mathrm{H}^{\beta}-\mathrm{H}^{\gamma}$ cross peaks of the glutamines, the glutamic acids and the prolines is difficult in protein COSY spectra because these are typically found in the region around the diagonal between 1.8 to $2.5 \mathrm{ppm}$, and only in a few favourable cases the $\mathrm{H}^{\beta}-\mathrm{H}^{\gamma}$ cross peak could be observed in these. However, often in NOESY spectra the cross peak of the $\mathrm{H}^{\alpha}-\mathrm{H}^{\gamma}$ dipolar coupling can be seen, and from this at least one of the $\mathrm{H}^{r}$ chemical shifts was measured. In glutamines and glutamic acid the $\mathrm{H}^{\gamma}-\mathrm{H}^{\gamma}$ cross peaks are relatively intense, hence from the information about one of the $\mathrm{H}^{\gamma}$ the other was found from the $\mathrm{H}^{\gamma 1}-\mathrm{H}^{\gamma 2}$ cross peaks. The $\mathrm{H}^{\gamma^{1}}-\mathrm{H}^{\gamma^{2}}$ cross peaks of the glutamic acid residues shift towards higher field with increasing $\mathrm{pH}$. In the COSY spectrum, Figure 7, are shown the six $\mathrm{H}^{\gamma 1} \cdot \mathrm{H}^{\gamma 2}$ cross peaks of the six glutamic acids at pH $3.28 \mathrm{pH} 4.20$ and $\mathrm{pH} 6.45$. The remaining three $\mathrm{H}^{\gamma 1}-\mathrm{H}^{\gamma 2}$ cross peaks which did not show the typical shift were assigned to glutamines, and identified in agreement with the sequential assignment.

The intact BSPI-2 contains in addition two glutamic acid residues, Glu-4 and Glu-8. The $\mathrm{H}^{\mathrm{N}}, \mathrm{H}^{\alpha}, \mathrm{H}^{\beta^{\prime}}, \mathrm{H}^{\beta^{\prime \prime}}$ resonances of these two residues are slightly different, however, for both residues these chemical shifts are close to those of glutamic acid in model peptides, Table $\mathrm{I},(10,54)$.

\subsubsection{Arginine, proline, lysine, leucine and methionine}

The assignment of the spin systems of the remaining five types of amino acids was based primarily on the information achieved in the sequential assignment that the $\mathrm{H}^{\mathrm{N}}-\mathrm{H}^{\alpha}$ cross peak according to sequential NOE's belonged to a given amino acid spin system in the sequence. Accordingly, the additional information available on the spin system considered, was examined in order to check that this corresponded to that expected for this type of amino acid.

For the prolines the $\mathrm{H}^{\gamma 1}-\mathrm{H}^{\gamma 2}$ resonances were assigned partly on $d_{\alpha \delta}(i, i+1)$ couplings in the NOESY spectra partly on their typical chemical shift values between 3 and $4.5 \mathrm{ppm}$. The assignment of the $\mathrm{H}^{\mathrm{a}}$ resonances of the four prolines Pro-25, Pro-44, Pro-52, and Pro-80 was based, partly on the finding that they were the only $\mathrm{H}^{\mathrm{a}}$ resonances which did not couple to an $\mathrm{H}^{\mathrm{N}}$ in the amide region and partly on the observation that three of the four in the NOESY spectrum were showing dipolar coupling to the subsequent $\mathrm{H}^{\mathrm{N}}$ in the sequence. The assignments of resonances of the $\mathrm{H}^{\beta}$ and the $\mathrm{H}^{\gamma}$ 's were obtained thus from the COSY and the $2 \mathrm{Q}$ spectra.

Given that the leucine $\mathrm{H}^{\mathrm{N}}, \mathrm{H}^{a}, \mathrm{H}^{\beta^{\prime}}, \mathrm{H}^{\beta^{\prime \prime}}$ resonances were assigned based on the sequential assignment and the $\mathrm{H}^{\gamma}-\mathrm{H}^{\delta 1(1,2,3)}, \mathrm{H}^{\gamma}-\mathrm{H}^{\delta 2(1,2,3)}$ of the leucines were distinguished from the valine $\mathrm{H}^{\beta}-\mathrm{H}^{\gamma(1,2,3)}, \mathrm{H}^{\beta}-\mathrm{H}^{\gamma(1,2,3)}$ cross peaks by the assignment of these latter, the search for $\mathrm{H}^{\beta}-\mathrm{H}^{\gamma} \mathrm{COSY}$ cross peaks was considerably narrowed but resulted nevertheless only in the complete identification of one leucine spin system, that of Leu27. The assignments of the remaining leucine spin systems were therefore based on intra-spin system NOE's from either the $\mathrm{H}^{\alpha}$ 's or from the $\mathrm{H}^{\beta}$ 's to the $\delta$-methyl groups. The assignment of five of the leucines was accomplished by these procedures and the assignment of the remaining Leu-20 spin system was based then on elimination and supported by the finding that the chemical shifts of this leucine spin system were identical to those found for leucine in model peptides $(10,54)$.

The assignment of the methionine, arginine and lysine spin systems was not fully accomplished in this work. For the arginines the five $\mathrm{H}^{\varepsilon}-\left(\mathrm{H}^{\delta 1}, \mathrm{H}^{\delta 2}\right)$ were observed and so were six of the eight $\mathrm{H}^{\zeta}-\left(\mathrm{H}^{\mathrm{\varepsilon} 1}, \mathrm{H}^{\varepsilon^{2}}\right)$ couplings of the lysines, however, only in case of Arg-62 a complete assignment was achieved partly based on NOE's from the $\mathrm{H}^{\alpha}$ to the $\mathrm{H}^{\gamma}$ 's. 


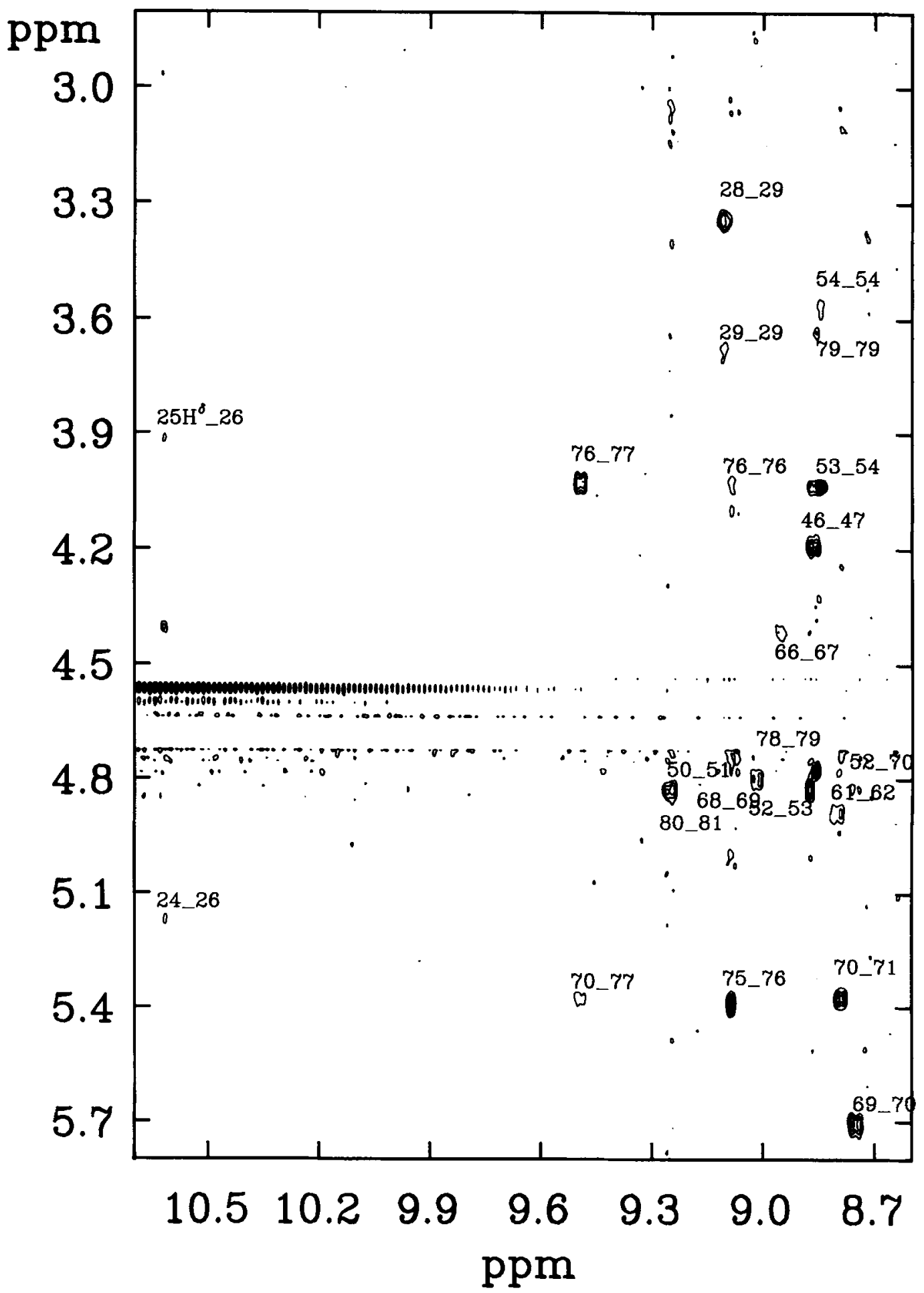

Figure 9. 'H-NOESY spectrum of (19-83)BSPI-2 conditions as described in Figure 8. The region shown is the $\mathrm{d}_{\alpha \mathrm{N}}$-region. The labelling scheme is as follows. The first sequence position is that of the $\mathrm{H}^{\mathrm{a}}$ whose chemical shift in the $\omega_{1}$-axis corresponds to the cross peak position and the second sequence position is then equally corresponding to the $\mathrm{H}^{\mathrm{N}}$ chemical shift position on the $\omega_{2}$-axis. NOE-cross peaks in which other proton types than $\mathbf{H}^{\mathrm{a}}$ and $\mathrm{H}^{\mathrm{N}}$ are involved have been labelled with Greek letters referring to the IUPAC-IUB recommendation. 
M. KJÆR et al.: Assignment of the BSPI-2 'H NMR spectrum

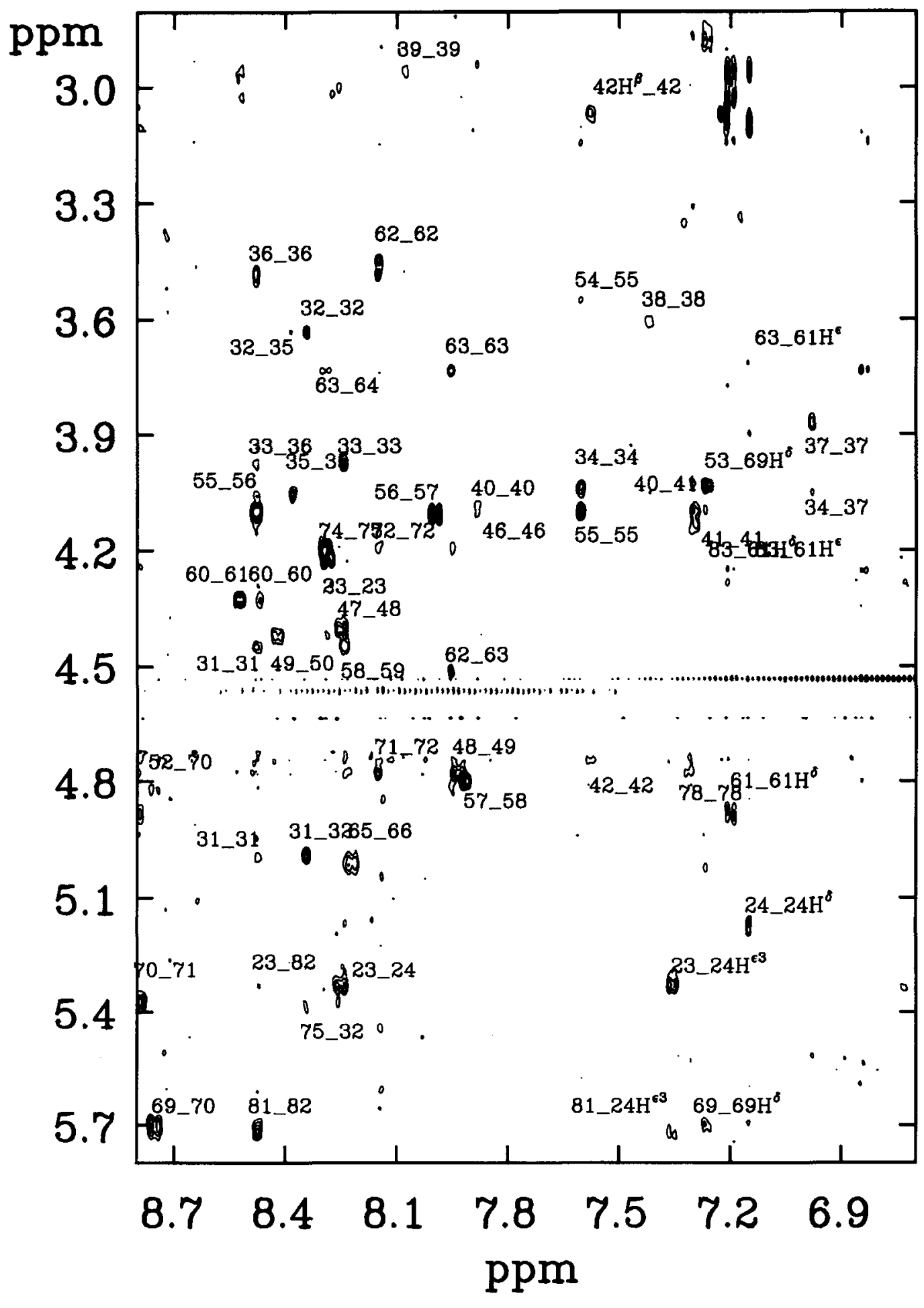




\section{ppm}
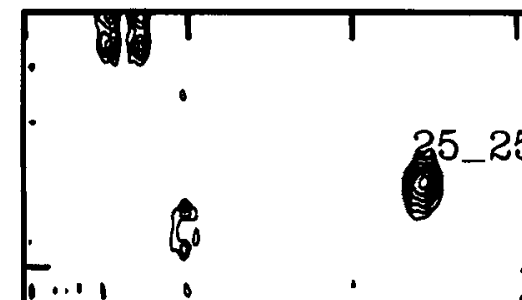

3.4

3.8

$79 \mathrm{H}^{\alpha}-80 \mathrm{H}^{\delta}$<smiles>C1CCCCC1</smiles>

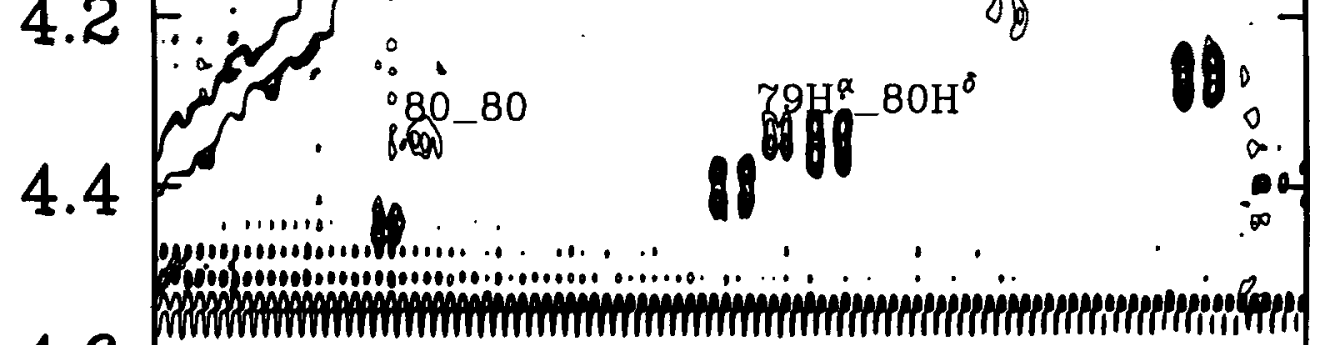

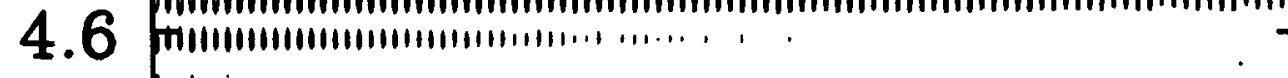

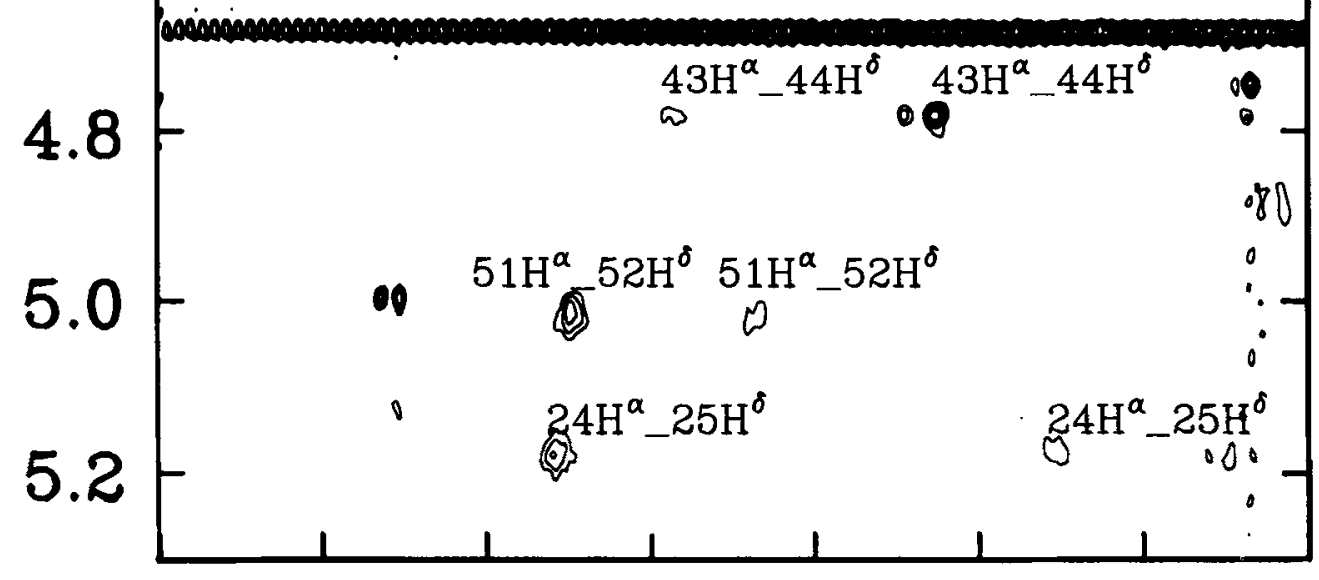

$\begin{array}{llllllll}4.4 & 4.2 & 4.0 & 3.8 & 3.6 & 3.4 & 3.2 & 3.0\end{array}$ ppm 
Figure $10 .{ }^{1} \mathrm{H}$-NOESY spectrum of (19-83)BSPI-2 as above. The spectrum shows the $\mathrm{d}_{\mathrm{ab}}(\mathrm{i}, \mathrm{i}+1)$ cross peaks involving the $\delta$ protons of the four prolines in the sequence.

\section{DISCUSSION}

The determination of the spatial structure of the BSPI-2 is one of the main aims for studying this protein by proton NMR spectroscopy. The sequence specific assignment of the proton NMR spectrum is a prerequisite for the assignment of the NOESY spectrum which again is the main basis for the determination of the three-dimensional structure. Such studies will be the subject of the subsequent papers, however, the results obtained of just the sequence specific assignments reveal some obvious features of the BSPI-2 structure which will be commented here. It is obvious from the studies that the intact BSPI- 2 is composed of two structurally different compartments. The $\mathrm{N}$-terminal part of the protein is clearly not engaged in forming a globular structure with the rest of the molecule for which both NMR spectroscopy and X-ray crystallography provide evidence for a well defined globular structure. The evidence for the lack of an ordered globular structure in the first 21 residues is based on the observation of the assigned NMR signals of the hydrogens of the amino acid residues 1 through 21. They have in common the following two features 1) the resonances have much smaller linewidths than those of the remaining part of the molecule and 2) the resonances of the protons concerned have chemical shifts very close to those measured for the equivalent resonances in random coil polypeptides. Furthermore, the sequential NOE's $d_{a N}(i, i+1)$ and $d_{N N}(i, i+1)$ which are common in globular proteins were not observed in NOESY spectra of the protein recorded with mixing times up to $0.300 \mathrm{~s}$ at $22{ }^{\circ} \mathrm{C}$. Each of these observations suggests that the first 21 residues of the BSPI- 2 do not engage in a well defined structure like the rest of the molecule. This is in agreement with the observations by X-ray crystallography that no reflections of the atoms of this part were observed $(29,30)$. It is also in agreement with the presence of the two forms of the protein BSPI-2 and (19-83)BPSI-2 in the extract of barley seeds where proteinases could easily hydrolyze off the amino acid residues of the unstructured part of BSPI-2.

It has previously (20) been shown that BSPI-2 exists in solution as a dimer. However, the NMR spectrum sofar assigned, reveals no signs of dual sets of resonances for particular protons, which might have been expected for protons at the interphase of the two monomer units in the

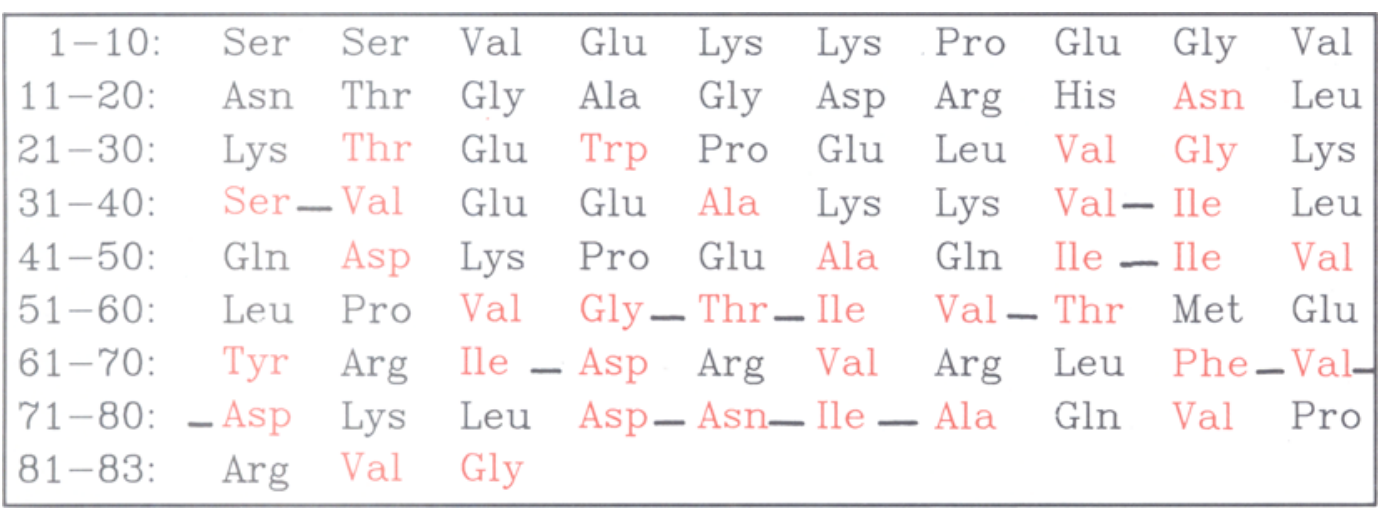

Figure 11. The amino acid sequence of BSPI-2. Unique pairs of amino acids involving one of the 11 types of amino acids first assigned are connected with a bar. The positions in which one of the 11 types occurs are indicated by red lettering. 
complex. A qualitative analysis, however, comparing the strongly shifted $\mathrm{H}^{\eta^{2}}$ and $\mathrm{H}^{\zeta^{3}}$ of Trp-24 with the structure determined by X-ray crystallography shows that neither Phe-69 or Tyr- 61 which are the only two other aromatic residues in BPSI-2 could be responsible for these shifts. It is a possibility, therefore, that the tryptophans of the two monomers in the complex are in close contact and oriented in such a way that they give rise to the observed shifts. A quantitative examination of all the ring current shifts and other chemical shift anisotropy effects calculated on the basis of the $\mathrm{X}$-ray structure and those observed is presently in progress in order to clarify this problem.

The sequential assignment procedure has relied on the chemically determined amino acid sequence, still however, the NMR study is at the same time an alternative method of examining the results of the chemical amino acid sequence determination. In particular, the positions in the amino acid sequence held by amino acids which are unambiguously identified by the NMR examination can be checked. The present work has in all respects confirmed the amino acid sequence as determined by automated amino acid sequencing and from the DNA-sequence of the gene (53).

The present work has resulted in the assignment of resonances of 447 hydrogen atoms in the structure of (19-83)BSPI-2. This corresponds to the assignment of $80 \%$ of the total number of protons whose resonances are normally expected in ${ }^{1} \mathrm{H}$ NMR-spectra of proteins. The complete assignment of the resonances from the arginines, lysines, and methionines is presently in progress.

\section{ACKNOWLEDGEMENTS}

We thank Professor MARTin OTtesen for critical reading of this manuscript. The BRUKER AM $500 \mathrm{MHz}$ NMR spectrometer was provided by the Danish Natural Science Research Council and the Carlsberg Foundation of Copenhagen. We thank the Institute of Organic Chemistry, The Technical University of Denmark for housing the spectrometer and we thank Dr. KLAUS BocK for help and advice, Dr. I. SVENDSEN for performing $\mathrm{N}$-terminal analysis of (19-83)BSPI-2 and checking the purity of the
N-terminal blocked BSPI-2. We also thank Jette Holsøe and ANNette Pettersson for assistance in preparing the manuscript and PIA MIKKELSEN for skilled technical asistance in preparing both (19-83)BSPI-2 and the BSPI-2. We thank Dr. I. JONASSEN for providing the first samples of BSPI-2.

\section{REFERENCES}

1. ANIL-KUMAR, R. R. ERNST \& K. WÜtHRICH: A twodimensional nuclear Overhauser enhancement (2D NOE) experiment for the elucidation of complete proton-proton cross-relaxation networks in biological macromolecules. Biochem. Biophys. Res. Comm. 95, 1-6 (1980)

2. ANIL-Kumar, G. WaGner, R. R. ERNST \& K. WUTHRICH: Buildup rates of the nuclear Overhauser effect measured by two-dimensional proton magnetic resonance spectroscopy: Implications for studies of protein conformation. J. Am. Chem. Soc. 103, 3654-3658 (1981)

3. ARSENIEV, A.S., V.I.KoNDAKOV, V.N. MaIOROV \& F. BYSTROV: NMR solution spatial structure of 'short' scorpion insectotoxin $\mathrm{I}_{5} \mathrm{~A}$. FEBS Lett. 165 , 57.62 (1984)

4. Aue, W.P., E. Bartholdi \& R.R. ERnst: Two-dimensional spectroscopy. Application to nuclear magnetic resonance. J. Chem. Phys. 64, 22292246 (1976)

5. Bachmann. P., W.P. Aue, L. Müller \& R.R. ERnSt: Phase separation in two-dimensional spectroscopy. J. Magn. Reson. 28, 29-39 (1977)

6. Billeter, M., W. Braun \& K. Wüthrich: Sequential resonance assignments in protein ${ }^{1} \mathrm{H}$ nuclear magnetic resonance spectra. Computation of sterically allowed proton-proton distances and statistical analysis of proton-proton distances in single crystal protein conformations. J. Mol. Biol. 155, 321-346 (1982)

7. Boyd, J.. C.M. Dobson \& C. Redfield: Correlation of proton chemical shifts in proteins using two-dimensional double-quantum spectroscopy. J. Magn. Reson. 55, 170-176 (1983)

8. Braun, W., G. Wagner, E. Wörgötter, M. VÁSÁK, J.H.R. KÄGI \& K. WÜthrich: Polypeptide fold in the two metal clusters of metallothionein-2 by nuclear magnetic resonance in solution. J. Mol. Biol. 187, 125-129 (1986)

9. Braunschweiler, L., G. Bodenhausen \& R.R. ERNST: Analysis of networks of coupled spins by multiple quantum NMR. Mol. Phys. 48, 535-560 (1983)

10. BUNDI, A. \& K. WÜthrich: Amino acid residues 
measured in aqueous solution of the linear tetrapeptides H-Gly-Gly-X-L-Ala-OH. Biopolymers 18, 285-297 (1979)

11. CARVER, J.A., R.M. COOKE, G. ESPOSITO, I.D. CAMPBELL, H. GREGORY \& B. SHEARD: A high resolution 'H NMR study of the solution structure of human epidermal growth factor. FEBS Lett. 205, 77-81 (1986)

12. Clore, G.M., M. Nilges, D.K. Sukumaran, A.T. BRÜNGER, M. KarPLUS \& A.M. GRONENBORN: The three-dimensional structure of a1-purothionin in solution: Combined use of nuclear magnetic resonance spectroscopy, distance geometry and restrained molecular dynamics. EMBO J. 5, 27292735 (1986)

13. Clore, G.M., A.M. Gronenborn, M. KJ Jer \& F.M. POULSEN: The determination of the three-dimensional structure of barley serine proteinase inhibitor 2 by nuclear magnetic resonance spectroscopy, distance geometry and restrained molecular dynamics. Protein Engineering 1, 305-311 (1987)

14. Clore, G.M., A.M. Gronenborn, M.N.G. James, M. KuÆR, C.A. MCPhalen \& F.M. Poulsen: Comparison of the solution and X-ray structure of barley serine proteinase inhibitor 2. Protein Engineering 1, 313-318 (1987)

15. Clore, G.M., D.K. Sukumaran, M. Nilges \& A.M. GRONENBORN: Three-dimensional structure of phoratoxin in solution: Combined use of nuclear magnetic resonance, distance geometry, and restrained molecular dynamics. Biochemistry 26 , 1732-1745 (1987)

16. Eich, G.. G. Bodenhausen \& R.R. ERnst: Exploring nuclear spin systems by relayed magnetization transfer. J. Am. Chem. Soc. 104, 3731-3732 (1982)

17. HoCH, J.C.: RIS Technical Memorandum 18t, Rowland Institute for Science, Cambridge, Mass., USA (1985)

18. Hyberts, S.G., W. Märki \& G. WaGner: Stereospecific assignments of side-chain protons and characterization of torsion angels in eglin c. Eur. J. Biochem. 164, 625-635 (1987)

19. Jeener, J. B.H. Meier,P. Bachmann \& R.R. Ernst: Investigation of exchange processes by two-dimensional NMR spectroscopy. J. Chem. Phys. 71, 4546-4553 (1979)

20. JONASSEN, I: Characteristics of Hiproly barley 1 . Isolation and characterisation of two water-soluble high-lysine proteins. Carlsberg Res. Commun. 45, 47-58 (1980)

21. JONASSEN, I.: Characteristics of Hiproly barley 2. Quantification of two proteins contributing to its high lysine content. Carlsberg Res. Commun. 45, 59-68 (1980)
22. KJER, M. \& F.M. POULSEN: Secondary structure of barley serine proteinase inhibitor 2 determined by proton nuclear magnetic resonance spectroscopy. Carlsberg Res. Commun. 52, 355-362 (1987)

23. KJAR, M. \& F.M. POULSEN: Assignment of the two-dimensional nuclear Overhauser spectrum of barley serine proteinase inhibitor 2. Carlsberg Res. Commun. (in preparation)

24. KLEVIT, R.E., G.P. DROBNY \& E.B. WAYGOOD: Twodimensional ' $H$ NMR studies of histidine-containing protein from Escherichia coli 1. Sequential resonance assignments. Biochemistry 25,7760 7769 (1986)

25. KLEvit, R.E. \& G.P. DRoBNY:Two-dimensional 'H NMR studies of histidine-containing protein from Escherichia coli 2 . Leucine resonance assignments by long-range coherence transfer. Biochemistry 25 , 7770-7773 (1986)

26. KLINE, A.D. \& K. WÜTHRICH: Secondary structure of the $\alpha$-amylase polypeptide inhibitor tendamistat from Streptomyces tendae determined in solution by 'H nuclear magnetic resonance. J. Mol. Biol. 183, 503-507 (1985)

27. MacuRA, S. \& R.R. ERNST: Elucidation of cross relaxation in liquids by two-dimensional NMR spectroscopy. Mol. Phys. 41, 95-117 (1980)

28. MARION, D. \& K. WÜTHRICH: Application of phase sensitive two-dimensional correlated spectroscopy (COSY) for measurements of ${ }^{1} \mathrm{H}-{ }^{1} \mathrm{H}$ spin-spin coupling constants in proteins. Biochem. Biophys. Res. Commun. 113, 967-974 (1983)

29. McPhalen, C.A., I. Svendsen, I. Jonassen \& M.N.G. JAMES: Crystal and molecular structure of chymotrypsin inhibitor 2 from barley seeds in complex with subtilisin Novo. Proc. Natl. Acad. Sci. USA 82, 7242-7246 (1986)

30. McPhalen, C.A. \& M.N.G. James: Crystal and molecular structure of the serine proteinase inhibitor CI-2 from barley seeds. Biochemistry 26 , 261-269 (1987)

31. Mikola, J. \& E.M. Soulimna: Purification and properties of an inhibitor of microbial alkaline proteinases from barley. Arch. Biochem. Biophys. 144, 566-575 (1971)

32. MÚller, L. \& R.R. ERNST: Coherence transfer in the rotating frame. Application to hereronuclear cross-correlation spectroscopy. Mol. Phys. 38, 963-992 (1979)

33. Neuhaus, D., G. Wagner, M. Vasá, J.H.R. KäGl \& K. WUTHRICH: Systematic application of highresolution, phase-sensitive two-dimensional ${ }^{\prime} \mathrm{H}$ NMR techniques for the identification of the amino-acid-proton spin systems in proteins. Rabbit mettalothionein-2. Eur. J. Biochem. 151, 257 273 (1985) 
34. Ohkubo, T., Y. Kobayashi, Y. Sihimonishi, Y. KYOGOKU, W. BRAUN \& N. Go: A conformational study of polypeptides in solution by ${ }^{1} \mathrm{H}-\mathrm{NMR}$ and distance geometry. Biopolymers 25, 123-134 (1986)

35. Piantini, U., O.W. Sørensen \& R.R. ERnst: Multiple quantum filters for elucidating NMR coupling networks. J. Am. Chem. Soc. 104, 6800-6801 (1982)

36. Rance, M., O.W. Sørensen, G. Bodenhausen, G. WAGNER, R.R. ERNST \& K WÜTHRICH: Improved spectral resolution in COSY $' H$ NMR spectra of proteins via double quantum filtering. Biochem. Biophys. Res. Comm. 117, 479-485 (1983)

37. StaTeS, D.J., R.A. HABERKORN \& D.J. RUBEN: A two-dimensional nuclear Overhauser experiment with pure absorption phase in four quadrants. $\mathbf{J}$. Magn. Reson. 48, 286-292 (1982)

38. Sukumaran, D.K., G.M. Clore, A. Preuss, J. Zarbock \& A.M. Gronenborn: Proton nuclear magnetic resonance of hirudin: Resonance assignment and secondary structure. Biochemistry 26 , 333-338 (1987)

39. StróP, P., G. Wider \& K. WÜthrich: Assignment of the ${ }^{1} \mathrm{H}$ nuclear resonance spectrum of the proteinase inhibitor IIA from bull seminal plasma by two-dimensional nuclear magnetic resonance at $500 \mathrm{MHz}$. J. Mol. Biol 166, 641-667 (1983)

40. SVENDSEN,I., B. MaRTIN\& I. JonasSEN: Characteristics of Hiproly barley 3. Amino acid sequences of two lysine-rich proteins. Carlsberg Res. Commun. $45,47-58$ (1980)

41. Svendsen, I., I. Jonassen, J. HejgaARd \& S. Boisen: Amino acid sequence homology between a serine protease inhibitor from barley and potato inhibitor 1. Carlsberg Res. Commun. 45, 389-395 (1980)

42. SVEndSEn, I., S. Boisen \& J. HejgaARd: Amino acid sequence of serine protease inhibitor CI- 1 from barley. Homology with barley inhibitor CI-2, potato inhibitor I and leech eglin. Carlsberg Res. Commun. 47, 45-53 (1982)

43. SVENDSEN I. \& I. JONASSEN: Identification of the reactive sites in two homologous serine proteinase inhibitors isolated from barley. Carlsberg Res. Commun. 47, 199-203 (1982)

44. Svendsen, I., J. HejgaARd \& J.K. Chavan: Subtilisin inhibitor from seeds of broad bean (Vicia faba);purification, amino acid sequence and specificity of inhibition. Carlsberg Res. Commun. 49, 493-502 (1984)

45. Ven, F.J.M vaN DE \& C.W. Hilbers: Residuespecific assignments of resonances in the ${ }^{1} \mathrm{H}$ nuclear magnetic resonance spectrum of ribosomal protein E-L30 by systematic application of two-dimensional fourier transform nuclear magnetic resonance methods. J. Mol. Biol. 192, 389-417 (1986)

46. VeN, F.J.M van DE \& C.W. HILbers: Sequential resonance assignments as a basis for the determination of a three-dimensional structure of protein E-L30 of Escherichia coli. J. Mol. Biol. 192, 419-441 (1986)

47. WAGNER, G. \& K. WÜthrich: Sequential resonance assignments in proteins ' $\mathrm{H}$ nuclear magnetic resonance spectra. Basic pancreatic trypsin inhibitor. J. Mol. Biol. 155, 347-366, (1982)

48. WAGNER, G. \& E.R.P. ZUIDERWEG: Two-dimensional double quantum ${ }^{1} \mathrm{H}$ NMR spectroscopy of proteins. Biochem. Biophys. Res. Comm. 113, 854-860 (1983)

49. WAGNER. G.: Two-dimensional relayed coherence transfer spectroscopy of a protein. J. Magn. Reson. 55, 151-156 (1983)

50. Wemmer, D. \& N.R. Kallenbach: Structure of apamin in solution: A two-dimensional nuclear magnetic resonance study. Biochemistry 22, 1901 1906 (1983)

51. Wider, G.. K.H. LeE \& K. WÜthrich: Sequential resonance assignments in protein ${ }^{~} \mathrm{H}$ nuclear magnetic resonance spectra. Glucagon bound to perdeuterated dodecylphosphocholine micelles. J. Mol. Biol. 155, 367-388 (1982)

52. WIDER, G., R.V. Hosur \& K. WÜTHRICH: Suppression of the solvent resonance in 2D NMR spectra of proteins in aqueous solution. J. Magn. Reson. $52,130-135$ (1983)

53. Williamson. M.S. J. Forde. B. Buxton \& M. KREIS: Nucleotide sequence of barley chymotrypsin inhibitor-2(CI-2) and its expression in normal and high-lysine barley. Eur. J. Biochem. 165, 99-106 (1987)

54. WÜthrich, K: NMR of Proteins and Nuclear Acids. (John Wiley \& Sons) (1986)

55. WÜthrich, K., G. Wider, G. WAGNER \& W. Braun: Sequential resonance assignment as a basis for determination of spatial protein structures by high resolution proton nuclear magnetic resonance. J. Mol. Biol. 155, 311-319 (1982)

56. ZARBOCK, J., G.M. Clore \& A.M. GronenBorn: Nuclear magnetic resonance study of the globular domain of chicken histone H5: Resonance assignment and secondary structure. Proc. Natl. Acad. Sci. USA 83, 7628-7632 (1986)

57. ZUIDERWEG, E.R.P., R. KAPTEIN \& K. WÜthRICH: Sequence-specific resonance assignments in the $' H$ nuclear-magnetic-resonance spectrum of the lac repressor DNA-binding domain 1-51 from Escherichia coli by two-dimensional spectroscopy. Eur. J. Biochem. 137, 279-292 (1983)

Accepted by S.O. ANDERSEN 